\section{$\mathrm{Y}-12$}

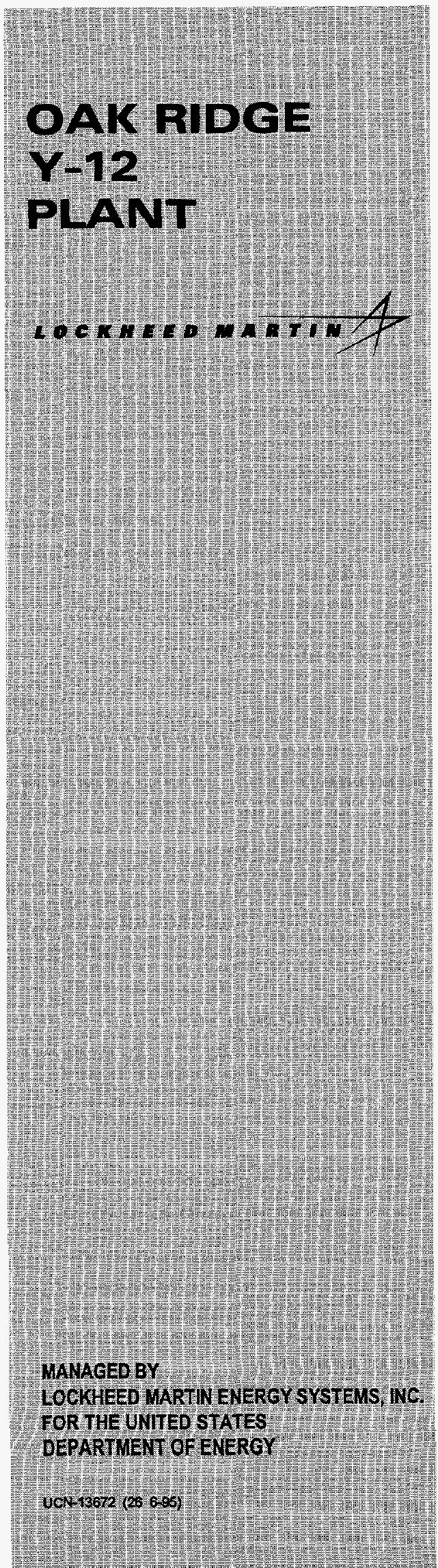

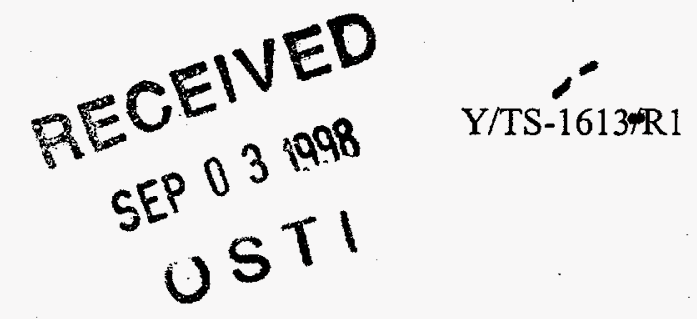

\author{
Oak Ridge Y-12 Plant \\ Biological Monitoring and \\ Abatement Program (BMAP) Plan
}
S. M. Adams
C. C. Brandt
D. S. Cicerone
S. W. Christensen
M. S. Greeley Jr.
W. R. Hill
M. A. Huston
L. A. Kszos
J. F. McCarthy
M. J. Peterson
M. G. Ryon
J. G. Smith
G. R. Southworth
A. J. Stewart

February 1998

Prepared for the

Oak Ridge Y-12 Plant

Oak Ridge, Tennessee 37831-8098

managed by

LOCKHEED MARTIN ENERGY SYSTEMS, INC. for the

U.S. DEPARTMENT OF ENERGY under contract DE-AC05-84OR21400 


\section{DISCLAIMER}

This report was prepared as an account of work sponsored by an agency of the United States Government. Noither the United States Government nor any agency thereof, nor any of their employees, makes any warranty, express or implied, or assumes any legal liability or responsibility for the accuracy, completeness, or usefulness of any information, apparatus, product, or process disclosed, or represents that its use would not infringe privately owned rights. Reference herein to any specific commercial product, process, or service by trade name, trademark, manufacturer, or otherwise, does not necessarily constitute or imply its endorsement, recommendation, or favoring by the United States Government or any agency thereof. The views and opinions of authors expressed herein do not necessarily state or reflect those of the United States Government or any agency thereof. 


\section{DISCLAIMER}

Portions of this document may be illegible in electronic image products. Images are produced from the best available original document. 


\title{
Oak Ridge Y-12 Plant Biological Monitoring and Abatement Program (BMAP) Plan
}

\author{
S. M. Adams \\ C. C. Brandt \\ D. S. Cicerone \\ S. W. Christensen \\ M. S. Greeley, Jr. \\ W. R. Hill \\ M. A. Huston
}

L. A. Kszos

J. F. McCarthy

M. J. Peterson

M. G. Ryon

J. G. Smith

G. R. Southworth

A. J. Stewart

February 1998

\author{
Prepared for the \\ Oak Ridge Y-12 Plant \\ Oak Ridge, Tennessee 37831-8098 \\ managed by \\ LOCKHEED MARTIN ENERGY SYSTEMS, INC. \\ for the \\ U.S. DEPARTMENT OF ENERGY \\ under contract \\ DE-AC05-84OR21400
}




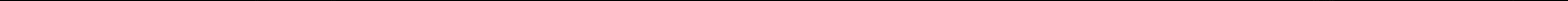




\section{Contents}

Page

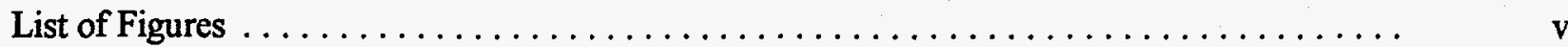

List of Tables $\ldots \ldots \ldots \ldots \ldots \ldots \ldots \ldots \ldots \ldots \ldots \ldots \ldots \ldots \ldots \ldots \ldots \ldots \ldots$

Acronyms and Abbreviations $\ldots \ldots \ldots \ldots \ldots \ldots \ldots \ldots \ldots \ldots \ldots \ldots \ldots \ldots \ldots \ldots \ldots \ldots$ vii

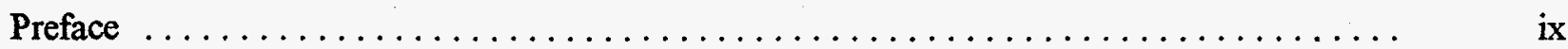

1. INTRODUCTION $\ldots \ldots \ldots \ldots \ldots \ldots \ldots \ldots \ldots \ldots \ldots \ldots \ldots \ldots \ldots \ldots \ldots \ldots$

1.1 DESCRIPTION OF THE STUDY AREA $\ldots \ldots \ldots \ldots \ldots \ldots \ldots \ldots \ldots \ldots \ldots \ldots \ldots$

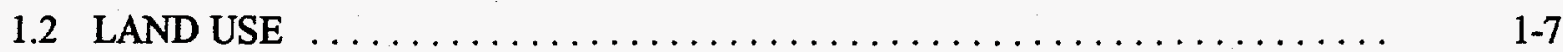

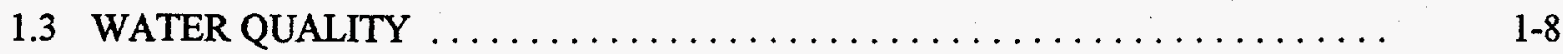

1.4 AMBIENT TEMPERATURE REGIMES $\ldots \ldots \ldots \ldots \ldots \ldots \ldots \ldots \ldots \ldots \ldots$

2. AMBIENT TOXICITY MONITORING (TASK 1)

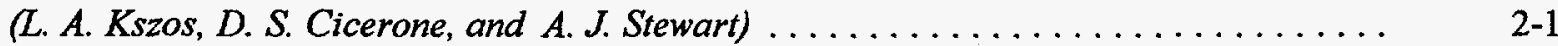

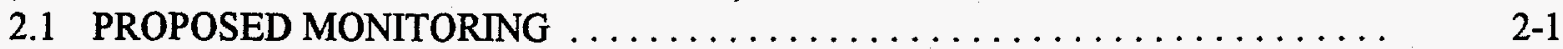

3. BIOACCUMULATION MONITORING (TASK 2)

(M. J. Peterson, G. R. Southworth, and J. F. McCarthy) ............... 3-1

3.1 BIOACCUMULATION OF CONTAMINANTS IN AQUATIC
ORGANISMS $\ldots \ldots \ldots \ldots \ldots \ldots \ldots \ldots \ldots \ldots \ldots \ldots \ldots \ldots \ldots \ldots \ldots \ldots \ldots$

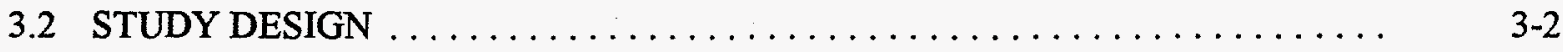

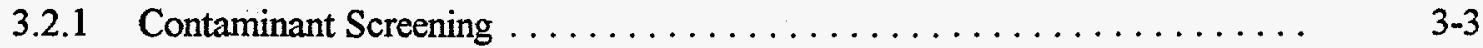

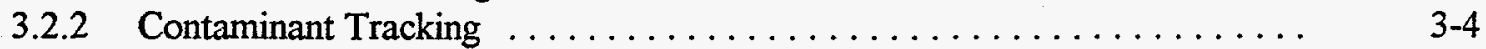

3.2 .3 Source Identification . . . . . . . .

3.3 STUDIES IN SUPPORT OF SITE SPECIFIC WATER QUALITY
CRITERION FOR MERCURY IN EFPC $\ldots \ldots \ldots \ldots \ldots \ldots \ldots \ldots \ldots \ldots \ldots \ldots \ldots$

3.3.1 Relationship Between Waterborne Mercury Species,

Sediment-Associated Mercury, and Accumulation of

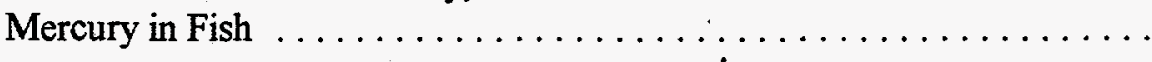

4. BIOLOGICAL INDICATORS OF CONTAMINANT-RELATED STRESS

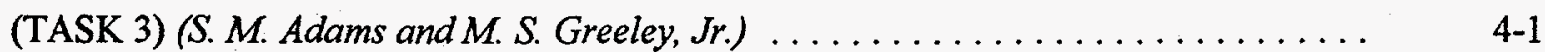

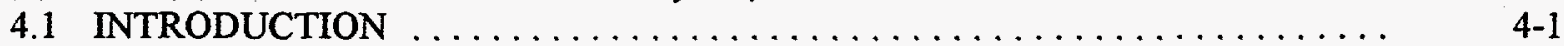

4.2 SYNOPSIS OF PAST AND PRESENT BIOLOGICAL

4.3 SYNOPSIS OF PAST RESULTS OF THE BIOLOGICAL
INDICATORS TASK 
4.4 BIOINDICATOR OF FISH HEALTH SUBTASK (SUBTASK 3a) $\ldots \ldots \ldots \ldots$

4.4.1 Bioindicator Response Measures . . . . . . . . . . . . . . . .

4.4.2 Indicators of Contaminant Exposure . . . . . . . . . . . . . .

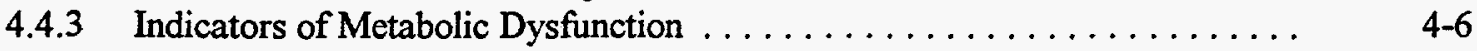

4.4.4 Indicators of Bioenergetic Function and Lipid Dynamics . . . . . . . . . . $4-6$

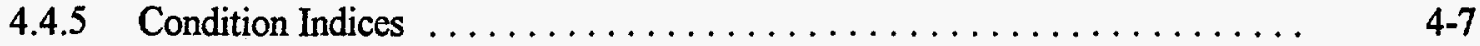

4.4.6 Indicators of Nutritional Status and Feeding $\ldots \ldots \ldots \ldots \ldots \ldots \ldots . \ldots \ldots$

4.4.7 Population-Level Indicators $\ldots \ldots \ldots \ldots \ldots \ldots \ldots \ldots \ldots \ldots \ldots \ldots \ldots$ 4-7

4.5 BIONDICATORS OF REPRODUCTIVE COMPETENCE SUBTASK

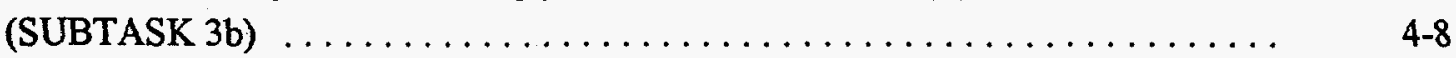

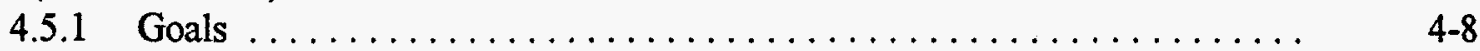

4.5.2 Reproductive Response Parameters . . . . . . . . . . . . . . . . $4-9$

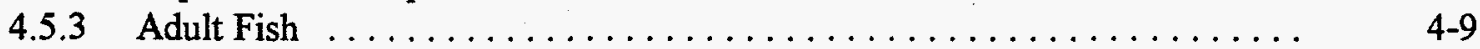

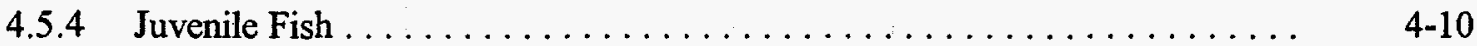

4.5.5 Embryo-Larval Tests $\ldots \ldots \ldots \ldots \ldots \ldots \ldots \ldots \ldots \ldots \ldots \ldots \ldots \ldots$ 4-10

4.6 SAMPLING DESIGN FOR THE BIOLOGICAL INDICATORS TASK . . . . . 4 4-10

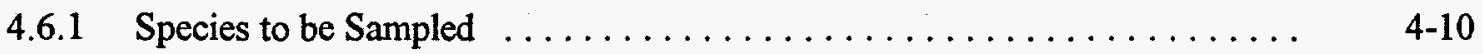

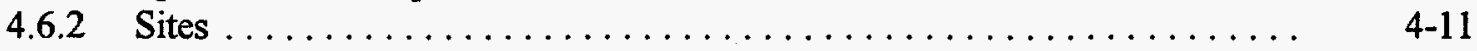

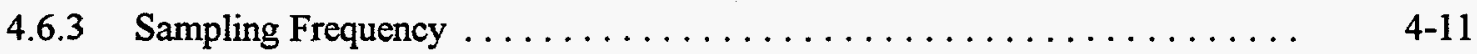

4.7 SPECIAL MERCURY AND FISH DEVELOPMENT STUDIES . . . . . $\ldots \ldots$ 4-12

5. INSTREAM ECOLOGICAL MONITORING (TASK 4) $\ldots \ldots \ldots \ldots \ldots \ldots \ldots \ldots$.

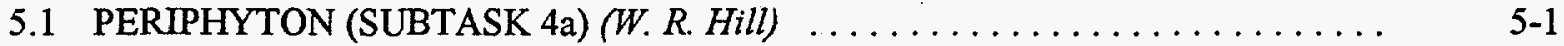

5.1 .1 Methods ..................................... $5-2$

5.2 BENTHIC MACROINVERTEBRATES (SUBTASK 4b) (J. G. Smith) . . . . . $\quad 5-3$

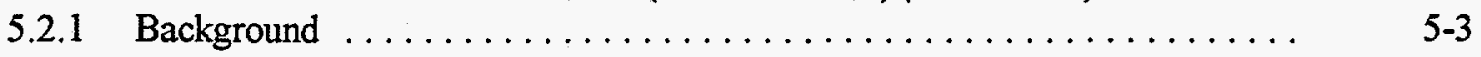

5.2 .2 Benthic Macroinvertebrate Monitoring Task Plan ............. $5-4$

5.3 FISH COMMUNITY STUDIES (SUBTASK 4c) $(M$. G. Ryon) . . . . . . . . $5-5$

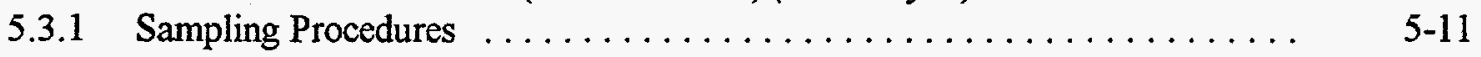

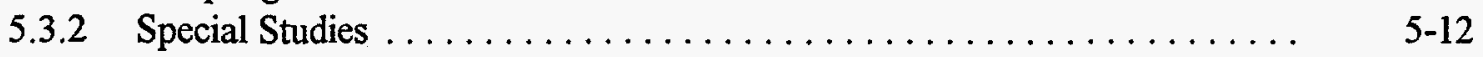

6. DATA INTEGRATION AND INTERPRETATION (TASK 5)

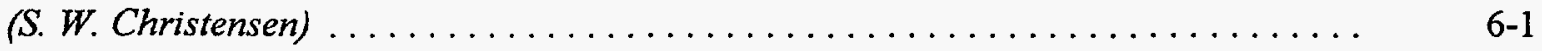

6.1 DATA INTEGRATION (SUBTASK 5a)

(S. W. Christensen and C. C. Brandt) ...................... $6-2$

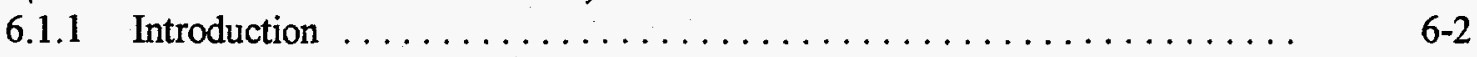

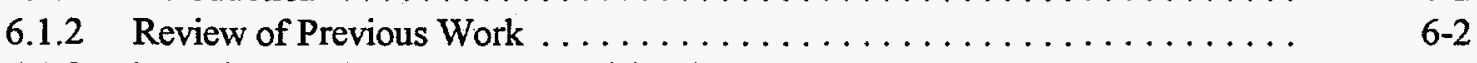

6.1.3 Description of planned approach/methodology .............. $6-3$

6.2 INTERPRETATION OF BIOTIC CHANGES (SUBTASK 5b)

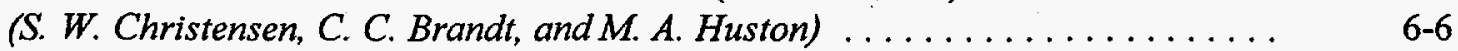

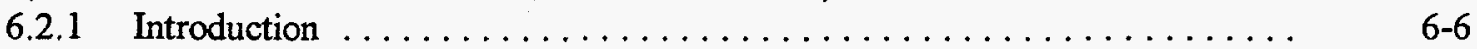

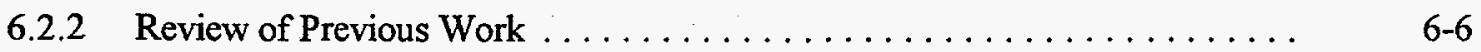

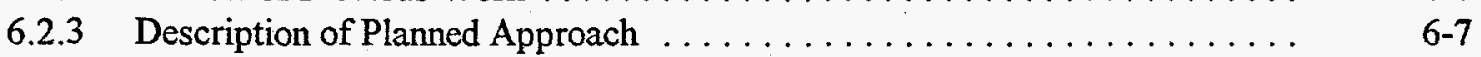

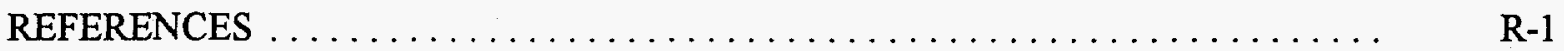




\section{List of Figures}

Figure

Page

1.1 Map of the East Fork Poplar Creek watershed showing the locations of the

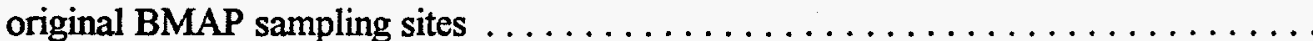

1.2 Map of the Oak Ridge area showing locations of the reference sites

1.3 Map of East Fork Poplar Creek as it flows through the Y-12 Plant ..........

5.1 Fish species richness trends at uppermost EFPC sites spring and fall, 1985-1995

5.2 Fish density trends at lowermost EFPC sites spring and fall, 1985-1995

5.3 Fish density trends at uppermost EFPC sites spring and fall, 1985-1995 


\section{List of Tables}

Table

2.1 Site designations, sample dates, and sites for the Ambient Toxicity

Monitoring Task

3.1 Bioaccumulation monitoring task outline of contaminant screening and tracking studies

4.1 Site designations, sample period, sample form, and status form for the

Biological Indicator Task.

5.1 Sites sampled in the Periphyton Community Task

5.2 Sites sampled for the Benthic Macroinvertebrate Community Studies Task

5.3 Site designations, sample dates, sites for electrofishing sampling of the

Fish Community Studies Task 


\section{Acronyms and Abbreviations}

\begin{tabular}{|c|c|}
\hline ALT & alanine aminotransferase \\
\hline AST & aspartate aminotransferase \\
\hline BF & Brushy Fork \\
\hline BFK & Brushy Fork kilometer \\
\hline BMAP & Biological Monitoring and Abatement Program \\
\hline BMP & best management practices \\
\hline BUN & blood urea nitrogen \\
\hline CASE & computer-aided systems engineering \\
\hline CDM & CDM Federal Programs Corporation \\
\hline CRERP & Clinch River Environmental Restoration Program \\
\hline CRK & Clinch River kilometer \\
\hline $\mathrm{CV}$ & coefficient of variability \\
\hline DOE & U.S. Department of Energy \\
\hline DOS & disk operating system \\
\hline EPA & U.S. Environmental Protection Agency \\
\hline ERDA & U.S. Energy Research and Development Administration \\
\hline EFK & East Fork Poplar Creek kilometer \\
\hline EFPC & East Fork Poplar Creek \\
\hline ESD & Environmental Sciences Division \\
\hline EROD & ethoxyresorufin O-deethylase \\
\hline EPT & Ephemeroptera, Plecoptera, Trichoptera \\
\hline FFA & Federal Facilities Agreement \\
\hline FS & Feasibility Study \\
\hline FY & fiscal year \\
\hline GAS & general adaption syndrome \\
\hline GIS & Geographic Information Systems \\
\hline GSI & gonadal-somatic index \\
\hline HCK & Hinds Creek kilometer \\
\hline IBI & Index of Biotic Integrity \\
\hline LR & Lake Reality \\
\hline MGD & million gallons per day \\
\hline MVS & mutiple virtual storage \\
\hline NHP & New Hope Pond \\
\hline NPDES & National Pollutant Discharge Elimination System \\
\hline NSP & North/South Pipes \\
\hline ORACLE & Oak Ridge Automatic Computer and Logic Engine \\
\hline OREIS & Oak Ridge Environmental Information System \\
\hline ORNL & Oak Ridge National Laboratory \\
\hline ORR & Oak Ridge Reservation \\
\hline ORTF & Oak Ridge Task Force \\
\hline ORWTF & Oak Ridge Wastewater Treatment Facility \\
\hline PAH & polycyclic aromatic hydrocarbons or polyaromatic hydrocarbon \\
\hline
\end{tabular}




$\begin{array}{ll}\text { PC } & \text { personal computer } \\ \text { PCB } & \text { polychlorinated biphenyl } \\ \text { PCK } & \text { Poplar Creek kilometer } \\ \text { PGDP } & \text { Paducah Gaseous Diffusion Plant } \\ \text { PORTS } & \text { Portsmouth Gaseous Diffusion Plant } \\ \text { PI } & \text { Principal Investigator } \\ \text { QA/QC } & \text { Quality Assurance/Quality Control } \\ \text { RI } & \text { Remedial Investigation } \\ \text { ROD } & \text { Record of Decision } \\ \text { RTL } & \text { Ready-to-Load } \\ \text { SAIC } & \text { Science Applications International Corporation } \\ \text { SAS } & \text { Statistical Analysis System } \\ \text { SOP } & \text { standard operating procedure } \\ \text { SPMD } & \text { semipermeable membrane devices } \\ \text { TOA } & \text { Tennessee Oversight Agreement } \\ \text { TSS } & \text { total suspended solids } \\ \text { TVA } & \text { Tennessee Valley Authority } \\ \text { USGS } & \text { U.S. Geological Survey } \\ \text { VMS } & \text { virtual memory system } \\ \text { WAG } & \text { Waste Area Grouping }\end{array}$




\section{Preface}

The proposed Biological Monitoring and Abatement Program (BMAP) for East Fork Poplar Creek (EFPC) at the Oak Ridge Y-12 Plant, as described, will be conducted for the duration of the National Pollutant Discharge Elimination System permit issued for the Y-12 Plant on April 28, 1995, and which became effective July 1,1995 . The basic approach to biological monitoring used in this program was developed by the staff in the Environmental Sciences Division at the Oak Ridge National Laboratory at the request of Y-12 Plant personnel. The proposed BMAP plan is based on results of biological monitoring conducted since 1985. Details of the specific procedures used in the current routine monitoring program are provided, but experimental designs for future studies are described in less detail. The overall strategy used in developing this plan was, and continues to be, to use the results obtained from each task to define the scope of future monitoring efforts. Such efforts may require more intensive sampling than initially proposed in some areas (e.g., additional toxicity testing if initial results indicate low survival or reproduction) or a reduction in sampling intensity in others (e.g., reduction in the number of sampling sites when no impact is observed). By using the results of previous monitoring efforts to define the current program and to guide us in the development of future studies, an effective integrated monitoring program has been developed to assess the impacts of the Y-12 Plant operation on the biota of EFPC and to document the ecological effects of remedial actions. 


\section{Introduction}

In May 1985, a National Pollutant Discharge Elimination System (NPDES) permit was issued for the Oak Ridge Y-12 Plant, in Oak Ridge, Tennessee. As a condition of the permit, a Biological Monitoring and Abatement Program (BMAP) was developed to demonstrate that the effluent limitations established for the Y-12 Plant protect the classified uses of the receiving stream [East Fork Poplar Creek (EFPC)], in particular, the growth and propagation of fish and aquatic life (Loar et al. 1989). A second objective of the BMAP was to document the ecological effects resulting from the implementation of a water pollution control program designed to eliminate direct discharges of wastewater into EFPC and to minimize the inadvertent release of pollutants to the environment. Because of the complex nature of the discharges to EFPC and the temporal and spatial variability in the composition of the discharges, a comprehensive integrated approach to biological monitoring was developed.

The BMAP originally consisted of four major tasks that reflect different but complementary approaches to evaluating the effects of the Y-12 Plant discharges on the biotic integrity of EFPC. These tasks included (1) toxicity testing, (2) bioaccumulation studies, (3) biological indicator studies, and (4) ecological surveys of the benthic macroinvertebrate and fish communities. The results of the original BMAP are summarized in Loar et al. (1992a) and Hinzman et al. (1993, 1995).

In the original BMAP, six primary study sites were selected on EFPC. Criteria used in the selection of these sites included (1) location of sampling sites utilized in other studies, (2) known or suspected sources of downstream pollution, (3) proximity to U.S. Department of Energy-Oak Ridge Reservation (DOE-ORR) boundaries, (4) concentration of mercury in adjacent floodplain, (5) appropriate habitat distribution, and (6) access. The sampling sites included EFPC at kilometer (EFK) 24.4 and EFK 23.4 [above and below Lake Reality (LR), respectively]; EFK 18.2, located off the ORR and below an area of intensive commercial and limited light industrial development and just above the area of greatest mercury contamination (Table 11 in TVA 1986); EFK 13.8, located approximately $400 \mathrm{~m}$ above the outfall of the Oak Ridge Wastewater Treatment Facility (ORWTF); EFK 10.0, located approximately $900 \mathrm{~m}$ below Gum Hollow Road bridge and $3.4 \mathrm{~km}$ below the ORWTF; and EFK 6.3, located approximately $1.4 \mathrm{~km}$ below the ORR boundary and $1.0 \mathrm{~km}$ above the U.S. Geological Survey (USGS) gaging station (Fig. 1.1). These sites were routinely sampled for fish and benthic invertebrates as part of the instream monitoring task (Sect. 5). For other tasks, sites may have been excluded and/or others added, depending upon the specific objectives of the various tasks. 


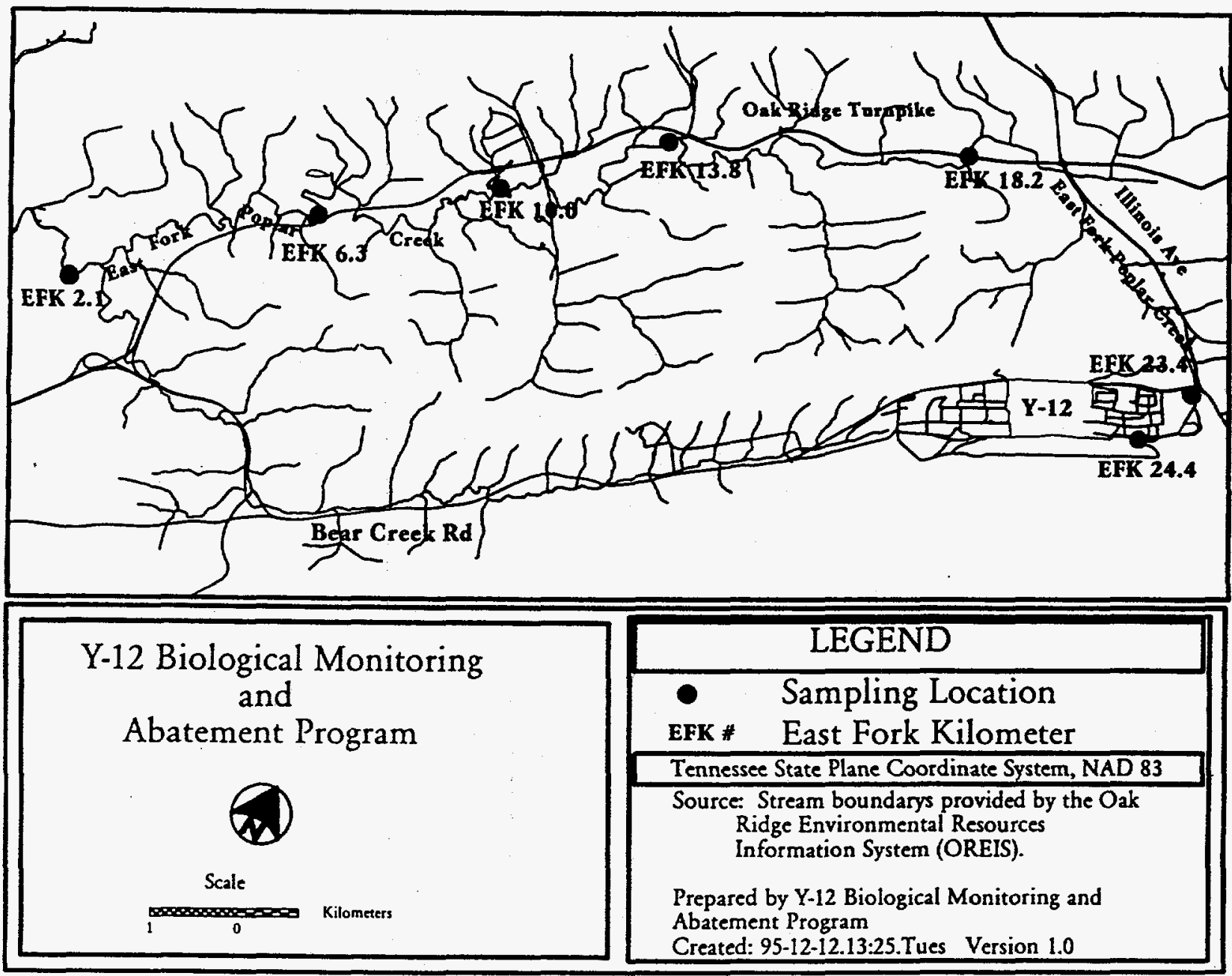

Fig. 1.1. East Fork Poplar Creek watershed and original BMAP sampling sites. 
Brushy Fork (BF) at kilometer (BFK) 7.6 was used as a reference stream in all four tasks of the BMAP. Additional sites off the ORR were also used for reference, including Beaver Creek, Bull Run, Hinds Creek, Paint Rock Creek, and the Emory River in Watts Bar Reservoir (Fig. 1.2).

A new NPDES permit was issued by the Tennessee Department of Environment and Conservation to the Y-12 Plant April 28, 1995, and became effective July 1, 1995. This revised BMAP plan meets the requirements of the new permit. The revisions are based on (1) documented changes in the ecological condition of EFPC since 1985 and (2) the need to evaluate the effects of continuing changes in the composition of discharges resulting from scheduled abatement and remedial actions at the Y-12 Plant.

To understand the nature and complexity of the existing environment, a brief description of the EFPC watershed is given below. Detailed descriptions of each task are presented in Sects. 2-6.

\subsection{DESCRIPTION OF THE STUDY AREA}

The EFPC drainage basin is located near the northern boundary of the ORR and has an area of $77.2 \mathrm{~km}^{2}$ from the headwaters to the mouth at Poplar Creek kilometer (PCK) 8.7." Parallel northeasttending ridges constitute the northern (Black Oak Ridge) and southern (Chestnut Ridge) boundaries of the watershed. Elevations in the basin range from 226 to $390 \mathrm{~m}$. The largest tributary to EFPC is Bear Creek, which has a drainage area of $19.1 \mathrm{~km}^{2}$ and joins EFPC at EFK 2.4." The Y-12 Plant is located near the watershed divide of Bear Creek and EFPC, which flow to the west and east, respectively, of the plant (Fig. 1.1).

The study area is located in the Valley and Ridge physiographic province of the Southern Appalachians. The ridges are composed primarily of sandstones and dolostones and the valleys are underlain by shales, limy shales, and limestones (Geraghty and Miller, Inc. 1985). The principal groundwater-bearing formation in the Oak Ridge area is the Knox Dolomite, which comprises 25 percent of the surface area of the EFPC drainage basin; another 32 percent of the area consists of Chickamauga Limestone.

The primary reference area used in the BMAP is the BF watershed located just north of Oak Ridge and adjacent to the EFPC watershed (Fig. 1.2). The two drainages, which are separated by Black Oak

* Poplar Creek Kilometer (PCK) 0.0 and East Fork Poplar Creek Kilometer (EFK 0.0) are located at the confluence of Poplar Creek with the Clinch River and at the confluence of East Fork Poplar Creek with Poplar Creek, respectively. All discharges are based on the list of key features described in Table $\mathrm{I}-1$ in TVA 1986. 
ORNL-DWG-95M-7421R

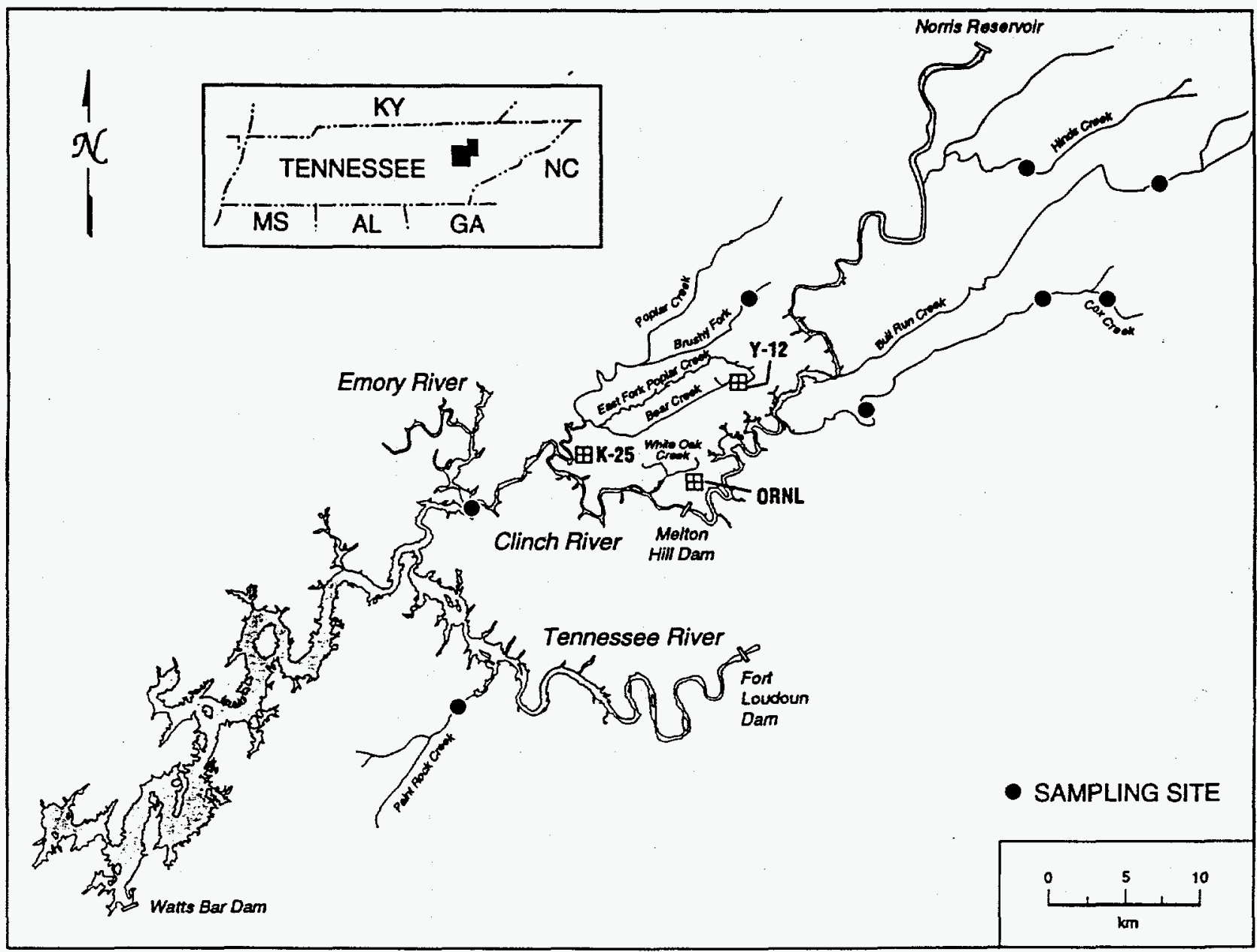

Fig. 1.2. Oak Ridge area and reference sites. 
Ridge, have similar geologic compositions. The Knox Dolomite that underlies Black Oak Ridge is the source of three large springs that are tributaries to BF above the study site (BFK 7.6). The almost identical unit-area, low-flow discharges $\left(\sim 0.95 \mathrm{~L}^{3} \cdot \mathrm{sec}^{-1} \cdot \mathrm{km}^{-2}\right)$ EFPC at EFK 5.3 and BF at BFK 10.1 provide additional evidence of the similarity in their geologic composition.

The headwaters of EFPC consist of springs on the northwest slope of Chestnut Ridge. The stream originates at the North/South Pipes (NSP) into a rip-rap channel approximately $2.4 \mathrm{~m}$ wide and $2.6 \mathrm{~m}$ high (Kasten 1986). In the past, the stream received discharges from more than 200 outfalls (M. C. Wiest, Y-12 Plant Department of Environmental Management, personal communication). These discharges included once-through cooling water, storm water, condensate, groundwater, cooling tower blowdown, and treated process wastewater (CDM Federal 1994).

Prior to November 7, 1988, EFPC flowed into New Hope Pond (NHP), a 2.2-ha impoundment constructed in 1963 to equalize the $\mathrm{pH}$ of the effluent from the Y-12 Plant (Pritz and Sanders 1982). The pond was also used for neutralization, sediment retention, and spill control (including provision for oil recovery by means of skimmers). Construction of a bypass (diversion) channel around NHP permitted retention of spills within the pond. On November 7,1988 , flow to the pond was terminated and directed to LR, a new 1-ha impoundment that is slightly deeper than NHP and has a synthetic liner (Fig. 1.3). In addition, the outfall from LR is lower in elevation than that of NHP, allowing the passage of fish into upper EFPC. From the outfall of LR, EFPC flows a distance of $23.4 \mathrm{~km}$ to the confluence with Poplar Creek, a tributary of the Clinch River. The average gradient between the upstream limits of the reservoir backwater area and LR is approximately $1.7 \mathrm{~m} / \mathrm{km}$ (TVA 1985 ).

Effluent discharges from the Y-12 Plant above LR and from the ORWTF at EFK 13.4 augment the streamflow of EFPC. The mean discharge at NPDES Station 17 downstream from the outfall of LR was $242 \mathrm{~L} / \mathrm{s}$ for the period 1988-1992 compared with a mean discharge from NHP of $411 \mathrm{~L} / \mathrm{s}$ for the period January 1985-June 1988. Flow reduction has been achieved in large part to routing of sink drains to the sanitary sewer, reduced operations, and water conservation practices. Since July 1996, approximately four million gallons of raw water per day are pumped from the Clinch River and are added to EFPC at a point approximately $50 \mathrm{ft}$ below NSP. This allows EFPC flow to be managed at 7 MGD at Station 17, as required by the NPDES Permit.

The collection of streamflow data for EFPC and Poplar Creek at the USGS gaging station (EFK 5.3 and PCK 22.2, respectively) was discontinued in 1988. A discussion of minimum and maximum flows in EFPC is presented in the First and Second Y-12 BMAP Reports for EFPC (Loar et al. 1992a and Hinzman 

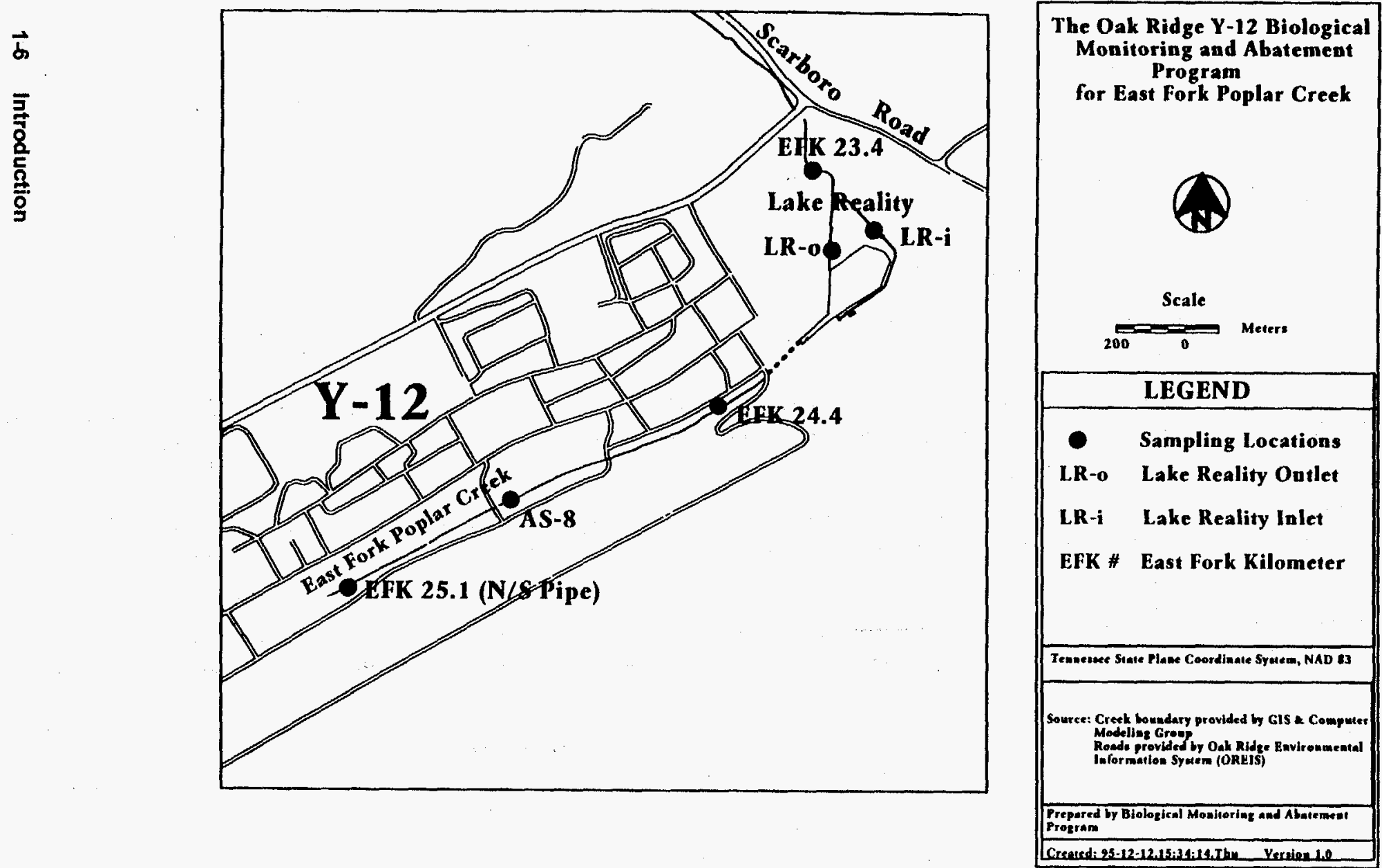

Fig. 1.3. East Fork Poplar Creek as it flows through the Y-12 Plant. The creek emerges from below ground at the North/South Pipes (NSP) and flows along a riprap channel through much of the plant. About $1.5 \mathrm{~km}$ downstream of the NSP, the creek flows through a diversion channel bypassing Lake Reality. 
et al. 1993, respectively). Daily flow data for EFK 5.3 are not currently available; however, past data have shown that minimum daily flows in EFPC are about an order of magnitude greater than minimum flows in streams of similar size that do not receive flow augmentation.

A characteristic of streamflow in EFPC is lower temporal variability due to the near-constant average daily discharge at the outfall of LR. This effect was especially evident from a comparison of the hydrographs for lower EFPC (EFK 5.3) and BF, a stream with no flow enhancement from industrial or municipal sources (Fig. 2-4 in Hinzman et al. 1993). A comparison of the coefficient of variability (CV) for several streams on the ORR in 1991, based on the mean monthly discharge values, ranged from 65 to 234 percent (Hinzman et al. 1993). The CV for flow at station 17 for 1991 was 38 percent, a two- to sixfold reduction. Although the increased minimum flow may benefit aquatic biota by reducing the risk of streambed dewatering, increased flow stability also lowers environmental heterogeneity (i.e., habitat diversity), which can adversely affect species richness and/or density.

\subsection{LAND USE}

Land use in the EFPC watershed reflects the public and private ownership of property in the basin. The creek flows less than $1 \mathrm{~km}$ below LR before leaving the ORR at EFK 22.7. For the next $15 \mathrm{~km}$, EFPC flows through the city of Oak Ridge, which had a population of 27,310 in 1990 (Southeast Directory Co., Inc. 1995), before crossing the ORR boundary again at EFK 7.7 for the remainder of its course. The lower portion of the watershed within the ORR is undeveloped, consisting mostly of pine plantations and mixed hardwood stands. Many pine plantations on the ORR have been destroyed as a result of pine beetle infestations.

Land use in Oak Ridge consists mostly of commercial and residential developments, some light industry and agriculture, and forested areas. Most of the industrial development is limited to the northeastern part of the basin. Drainage from this area enters EFPC between EFK 22.5 and EFK 21.5. Commercial development occupies much of the floodplain and adjacent areas of the creek from EFK 22.5 to EFK 18.0. Farther downstream to the ORR boundary, residential and some agricultural development (primarily livestock grazing) occur. Construction of single and multifamily homes between EFPC and Route 95 (Oak Ridge Turnpike), which parallels EFPC west of Oak Ridge, continues to increase. 


\subsection{WATER QUALITY}

Water and sediments in EFPC downstream from the Y-12 Plant contain metals, organic chemicals, and radionuclides discharged over many years of operation. Most of the information about these contaminants was obtained in studies conducted by the Tennessee Valley Authority (TVA) for the Oak Ridge Task Force (ORTF), a multiagency group established in November 1983 to evaluate potential offsite contamination problems associated with the DOE facilities near Oak Ridge. Prior to 1983, the only surveys of ambient water quality in EFPC below NHP (currently LR) were those conducted in 1961-1964 (McMaster 1967) and 1974-1975 (ERDA 1975).

The ORTF survey involved extensive sampling both on and off the ORR. Water samples were taken at EFK 23.1 during the baseflow survey and analyzed for conventional parameters, priority pollutants (organics and metals), and radionuclides; only lithium and mercury exceeded background levels (Table 3 in TVA 1986). Sediment samples were collected from EFPC and the floodplain near EFK 21.7 and EFK 2.7 and from the western and eastern ends of NHP; samples were analyzed for 114 organics, 14 metals, and 12 radionuclides (Table $I$ in Hoffman et al. 1984). Of these, ten priority pollutants [seven polycyclic aromatic hydrocarbons or PAHs, bis (2-ethyl hexyl) phthalate, total polychlorinated biphenyls (PCBs) and total phenols] and seven metals (arsenic, cadmium, lead, mercury, nickel, silver, and zirconium) were found in EFPC at concentrations above background levels and/or above the analytical detection limit (Table 4 in TVA 1986). Additional and more extensive sampling of sediments in EFPC was conducted to estimate the quantity of mercury-contaminated sediment and floodplain deposits and to assess the transport and/or stability of mercury-contaminated sediment in the EFPC watershed (TVA 1985).

Water quality characterizations for BMAP have been based on analyses of NPDES data collected at the outfalls of NHP (before November 1988) and LR (Stations 303 and 17, respectively). Additional information was provided from supplemental analyses conducted in various subtasks of the BMAP, including (1) routine measurements of several conventional parameters as part of the toxicity testing protocol (Sect. 2.1) and (2) nonroutine water and sediment sampling as part of the bioaccumulation and periphyton tasks, respectively (Sects. 3 and 5). Elevated levels of copper, lithium, mercury, ammonia, nitrogen, residual chlorine, and perchloroethylene were identified and discussed in previous reviews (Loar et al. 1992a). Water in EFPC is enriched in nutrients (nitrogen and phosphorus) that stimulate biological activity. Mercury levels were of particular concern in that the mean and maximum values exceeded the Environmental Protection Agency (EPA) chronic value of $1.2 \mu \mathrm{g} / \mathrm{L}$ (EPA 1986) over the 1988-1991 study period (Hinzman et al. 1995). Concentrations of total residual chlorine were of concern prior to 1992 , 
when a dechlorination project was implemented in upper EFPC. Studies to evaluate the effects of lithium and mercury to aquatic biota in EFPC are ongoing.

Lower EFPC and its floodplain have been the subject of a remedial investigation (RI) and feasibility study (FS) that have culminated in a Record of Decision (ROD). Under the ROD that was signed August 18, 1995, areas of the EFPC floodplain containing soil contaminated with $>400 \mathrm{mg}$ mercury $/ \mathrm{kg}$ will be excavated, and the soil will be replaced with clean soil (SAIC 1995). The decision is based on administrative record for Lower EFPC, including the RI report (DOE 1994a), the baseline risk assessment, the FS report (DOE 1994b), the addendum to the RI (DOE 1994c) that includes the sediment toxicity special study, the proposed plan (DOE 1995a,b), and other documents contained in the administrative record file for the site (DOE 1995c).

Results from the first phase of the soil, sediment, groundwater, and surface sampling in the RI showed detectable levels of 13 heavy metals, 9 PAHs, 2 PCBs, and 11 radionuclides (DOE 1994a, 1995c). For heavy metals, mercury was by far the most significant contributor of human health risk, with over 85 percent of the total toxicity. For radionuclides, total uranium accounted for 98 percent of the total activity. The organic compound groups of PAHs and PCBs did not substantially contribute to the estimated risks to human health. Risk associated with exposure to radionuclides fell within the EPA acceptable target range in all cases. The results of the baseline human health assessment confirmed mercury as the predominant contaminant of concern in Lower EFPC (DOE 1995c).

The RI (DOE 1994a) concluded that there is ongoing risk to ecological resources, especially aquatic organisms in the upper part of the creek, from exposure to contaminants in environmental media and food. Mercury was the primary contaminant of concern in the sediment and floodplain soils. PCBs were a contaminant of concern associated with biota (DOE 1995c). Toxicity studies (DOE 1994c) showed no toxicity to test organisms from chemicals extracted when sediment was suspended in water. Sedimentbased food chain effects were also evaluated (DOE 1995a). The food chain is the most important exposure pathway for terrestrial organisms (DOE 1995c). Initial results from the RI report (DOE 1995c) indicated that there are potential risks to terrestrial organisms. Additional studies were conducted to determine the relationship of apparent risks to soil mercury concentrations (DOE 1994c). These studies included analysis of organisms exposed in wetlands and expanded analysis of mercury content in vegetation. These studies concluded that there is no threat to plant communities from mercury in floodplain soils. Mercury concentrations in some floodplain soils are a potential threat to biota by exposure through the food chain 
(DOE 1995c). Ecological monitoring will be conducted under a separate plan to confirm that the remedial action carried out under the ROD for Lower EFPC is protective of the environment (SAIC 1995).

\subsection{AMBIENT TEMPERATURE REGIMES}

Water temperatures were monitored at five sampling locations in EFPC downstream of LR, one site upstream of LR, and in BF. Mean water temperatures were generally $4-7^{\circ} \mathrm{C}$ higher in EFPC just below LR (EFK 23.4) than in BF. Although temperatures frequently exceed $25^{\circ} \mathrm{C}$ below LR, the maximum temperature in $\mathrm{BF}$ seldom exceeds $25^{\circ} \mathrm{C}$. A longitudinal gradient of decreasing temperature was characteristic of EFPC; the only exceptions to this trend were the higher mean monthly temperatures in the winter at EFK 10.0 compared with EFK 13.8 and the lower maximum temperatures in the summer at EFK 10.0 compared with EFK 6.3. Such trends at EFK 10.0 may be indicative of inputs from springs, which are known to occur in this region, and/or discharges from the ORWTF at EFK 13.4 (Fig. 1.1). Water temperatures at EFK 24.4 inside the Y-12 Plant are generally similar to those at EFK 23.4 in the summer and $2-4^{\circ} \mathrm{C}$ warmer in the winter. Warmer winter temperatures may be attributed to the proximity of the site to several discharges (e.g., NSP).

Under this plan, water temperatures will be monitored continuously at three sites below LR (EFKs 23.4, 13.8 and 6.3), one site above LR (EFK 24.4), and BF." Temperature monitoring will be discontinued at EFK 10.0 because the fish and benthic community task are eliminating sampling at that site. Because there is little difference in the temperature data being collected at EFKs 13.8 and 18.2, monitoring at EFK 18.2 will also be discontinued. Since July 1996, a temperature drop of approximately $5^{\circ} \mathrm{C}$ has been observed along the length of upper EFPC. This is due to the Flow Management Project, which is providing approximately four million gallons of raw water per day to EFPC immediately below NSP.

\footnotetext{
**Water temperatures were collected through April 1987 at 2-h intervals using a Peabody Ryan Model J90 thermograph. Data were keypunched into data files on the IBM 3330 system as SAS data sets. Temperature data were collected with a Ryan Tempmentor after April 1987 at 20-min intervals through July 1,1987 , and at $1-h$ intervals after July $1,1987$. 


\title{
2. Ambient Toxicity Monitoring (Task 1)
}

\author{
L. A. Kszos, D. S. Cicerone, and A. J. Stewart
}

The ambient toxicity monitoring task includes two subtasks: toxicity monitoring and contaminant dynamics. Toxicity monitoring will use EPA-approved tests with Ceriodaphnia dubia to provide systematic information that can be used to determine changes in the biological quality of water in EFPC through time. In the past, systematic application of ambient toxicity test methods were used to (1) identify chlorine (or chlorine-like oxidants) as an important toxicant in upper EFPC, (2) determine if naturally occurring particulate matter in upper EFPC influenced the outcome of ambient toxicity tests with Ceriodaphnia, and (3) demonstrate that naturally occurring pathogens could reduce the survival of fathead minnow larvae. Thus, the toxicity monitoring task has been an effective component of the BMAP program and will be continued, albeit in reduced form. Studies on the influence of the biota on the contaminant dynamics will provide useful information on processes that modulate the form, flux, and biological availability of the persistent contaminants, such as metals and PCBs. The two subtasks are described in more detail below.

\subsection{PROPOSED MONITORING}

\section{Toxicity Monitoring (Subtask 1a)}

Water from two sites in EFPC upstream from Bear Creek Road [(EFK 24.1) and Outfall 201 (EFK 25.1); see Fig. 1.3 and Table 2.1] will be tested quarterly for acute and chronic toxicity to Ceriodaphnia using standard EPA-approved procedures. Outfall 201 is tested in accordance with the Y-12 Plant NPDES permit. The use of Ceriodaphnia only in this testing strategy is justified based on previous statistical analyses of ambient toxicity data (Stewart and Kszos 1990). Those studies analyzed site-to-site and test-to-test variance ratios, demonstrating that the Ceriodaphnia 7 -d toxicity test system was nearly four times "better" than the fathead minnow 7-d toxicity test system at detections. Ceriodaphnia appear to be intrinsically more sensitive than fathead minnow larvae to diverse contaminants, including nickel (Kszos et al. 1992), lindane (Constable and Orr 1994), and chemically complex effluents (Stewart et al. 1990). The Ceriodaphnia toxicity test system also has inherent statistical advantages, relative to the fathead minnow test system, due to the metrics that are used (counts of offspring versus growth of larvae) and the number of replicates typically employed (10 for Ceriodaphnia vs. 4 or 
Table 2.1. Site designations, sample dates, and sites for the Ambient Toxicity Monitoring task

\begin{tabular}{ccc}
\hline Site & Sample Dates & Test Frequency \\
\hline EFK $^{b} 25.1$ & Jun. 1990 - Present & Quarterly \\
EFK 24.1 & Dec. 1988 - Present & Quarterly \\
\hline
\end{tabular}

aTesting under this plan to be conducted with Ceriodaphnia only.

${ }^{\circ}$ East Fork Poplar Creek kilometer.

5 for fathead minnows). The majority of the toxicity test failures at these two upstream sites has been caused by chlorine (Stewart et al. 1996), which now has been largely eliminated.

On each day of each 7-d Ceriodaphnia test, portions of each water sample will be analyzed for $\mathrm{pH}$, conductivity, alkalinity, hardness, total residual chlorine, and total suspended solids (TSS). All of these parameters, except for TSS, were routinely measured in toxicity tests conducted under the previous BMAP. The addition of TSS is warranted because (1) many contaminants partition onto clays and organic particles and, thus, are co-transported with TSS by storm flows; (2) EPA's storm water regulations are likely to emphasize monitoring and control of TSS as an area-source pollutant in the future; (3) greater inputs of TSS to ORR streams from point- and area-sources are likely as various remedial actions are implemented; (4) the in stream ecological effects of TSS on grazing invertebrates and periphyton are at best poorly. understood; and (5) TSS may significantly affect periphyton communities and alter food-web conditions. Even a thin film of settled solids, for example, can substantially reduce the amount of light available to sustain photosynthesis by periphytic algae and may alter quality of the material consumed as food by grazing invertebrates. Measurements of TSS in water samples from each site will be collected during the first 4 to 8 Ceriodaphnia toxicity test periods and will be terminated if turbidity data from the DataSonde III monitoring units can be reliably related to TSS data through regressions.

\section{In-Stream Particle Retention Study (Subtask 1b)}

Many streams, including EFPC, tend to accumulate gravel in stream or bank-side structures referred to as gravel bars. Gravel bars develop primarily within riffle areas or near stream-channel bends where water-velocity changes are large; these formations can be altered in place, added to, subtracted from, or moved about wholesale by flood events (cf. Power and Stewart 1986). In-stream gravel bars can trap fine

\section{2-2 Ambient Toxicity Monitoring}


particles such as algae and silt being transported downstream during periods of base flow and can release the accumulated fine particles when the gravel is disturbed by elevated flows resulting from large precipitation events. Since contaminants that are sparingly soluble in water typically bind or sorb to fine particulate matter in aquatic habitats, we suggest that gravel bars in upper EFPC may be sites where particulate-phase pollutants may temporarily accumulate, or become transformed through microbial processes, before being carried farther downstream by flood events.

We will obtain estimates of deposition rates of fine particulate matter to gravel-bedded areas in upper EFPC by deploying gravel-filled trays containing "clean" (i.e., field-sieved) gravel and measuring the quantity of fine particulate matter that accumulates in the pans over specified periods of time during baseflow conditions. The particulate matter trapped in the pans will be collected onto glass-fiber filters, dried, weighed, ashed, and re-weighed to determine its composition (organic and inorganic); these data will be expressed as mass accumulated per area of gravel-bed per unit time, thereby providing estimates of particle flux to gravel. We will physically disturb a gravel bar during a low-flow period (thereby forcing it to "give up" previously trapped particles), then re-disturb the bar seven to ten days later, after it has trapped "new" particles. An instrument capable of monitoring turbidity will be deployed downstream of the bar during the second disturbance event to provide time-integrated estimates of turbidity exported from the bar. During the second disturbance event, we will also collect 10 to 12 grab samples of water from near the turbiditymonitoring instrument and analyze them in the laboratory for mass and composition, as described above. These data will allow us to relate exported turbidity (which can be measured reliably at 1-minute intervals) to exported particle mass. Funds permitting, representative subsamples of the material exported during the second disturbance event will also be analyzed for mercury and PCBs. With information on the mass of particles exported from the bar and an estimate of the concentration of specific contaminants per unit mass of particles, we can determine the significance of stream-bed gravel to contaminant movement patterns in the stream. 


\title{
3. Bioaccumulation Monitoring (Task 2)
}

\author{
M. J. Peterson, G.R. Southworth and J. F. McCarthy
}

\subsection{BIOACCUMULATION OF CONTAMINANTS IN AQUATIC ORGANISMS}

Bioaccumulation monitoring conducted since 1985 as part of the EFPC BMAP has identified mercury and PCBs as substances that accumulate to concentrations in fish that may pose health concerns to human consumers (Loar et al. 1992a, Hinzman et al. 1993). PAHs have been found to accumulate in invertebrates (but not fish) in EFPC and may be associated with impacts on indicators of fish health observed in Task 3 of the BMAP (Loar et al. 1992a, Hinzman et al. 1993).

Prior to replacement of NHP with LR, mercury concentrations in redbreast sunfish (Lepomis auritus) averaged in excess of $1 \mu \mathrm{g} / \mathrm{g}$ wet wt in EFPC at the discharge of NHP and decreased steadily with distance downstream, averaging about $0.4 \mu \mathrm{g} / \mathrm{g}$ near the mouth of EFPC (Loar et al. 1992a, Hinzman et al. 1993, Kornegay et al. 1993). Concentrations of mercury in this species have exhibited no increasing or decreasing trend over the 1985-1994 time period at sites in EFPC $5 \mathrm{~km}$ or more downstream from the Y-12 Plant, but the average concentration of mercury in fish in EFPC at the LR discharge has dropped from $1.3 \mu \mathrm{g} / \mathrm{g}$ before replacement of NHP in November 1988 to $0.8 \mu \mathrm{g} / \mathrm{g}$ following that action. Colonization of EFPC upstream of LR, which was restricted by toxic concentrations of residual chlorine prior to December 1992, has exposed fish to a reach of EFPC containing higher concentrations of waterborne mercury than occurred below LR or NHP in the past. Mercury concentrations in fish from this reach of stream exceeded $1.5 \mu \mathrm{g} / \mathrm{g}$ from 1992 to 1994.

Aggressive efforts are under way at the Y-12 Plant to reduce mercury loading and concentrations in EFPC. Substantial reductions have been attained in 1992-1994, and expectations are that further reductions will be achieved in the next 5 years. Continued routine monitoring of mercury in fish is needed to document the effects of these actions, both near the Y-12 Plant discharge and farther downstream where historical deposits of mercury may be significant sources of contamination in fish. Additionally, data obtained in this monitoring will provide a stronger scientific basis for determining the relationship between aqueous inorganic mercury concentrations and the accumulation of methylmercury by fish. Knowledge of that relationship is a key to being able to predict the degree of mercury contamination in fish that will occur with any given mercury loading to EFPC.

Although NPDES monitoring of PCBs in Y-12 Plant discharge water has not indicated the presence of PCBs above the analytical detection limit of $0.5 \mu \mathrm{g} / \mathrm{L}, \mathrm{PCB}$ contamination is evident in fish throughout 
the length of EFPC (Loar et al. 1992a, Hinzman et al. 1993, Kornegay et al.1993). Highest concentrations occur at sites nearest the Y-12 Plant, where colonization of LR and EFPC upstream has resulted in exposure of sunfish to higher concentrations of PCBs. As was the case with mercury, mean concentrations in sunfish decrease steadily with distance downstream. Over the 1988-1994 time period, average PCB concentrations in redbreast sunfish have not changed substantially at sites in middle and lower EFPC; but in upper EFPC, mean PCB concentrations have increased since December 1993. Since that time, mean PCB concentrations in redbreast sunfish from the three uppermost sites in upper EFPC routinely exceed the U.S. Food and Drug Administration threshold limit of $2 \mathrm{ppm}$. Continued monitoring of sunfish is needed to document the effectiveness of source reduction efforts. Monitoring of PCB contamination in largemouth bass, an uncommon species in most of EFPC but recently abundant in LR, is needed to provide a better estimate of maximum concentrations accumulated by large fish in EFPC. Carp have filled that role in EFPC monitoring to date; however, it is appropriate to include largemouth bass, an important game fish, if their abundance warrants it.

The bioaccumulation monitoring task has three primary objectives:

1. Contaminant screening - to identify contaminants that accumulate in aquatic organisms and to determine the degree of contamination;

2. Contaminant tracking - to evaluate spatial and temporal changes in contamination of aquatic life in order to evaluate actions intended to reduce contaminant inputs or availability; and

3. Source identification - to identify sources of contamination and determine pathways and processes of transport from source to aquatic organisms.

\subsection{STUDY DESIGN}

Routine monitoring of mercury and PCB contamination in redbreast sunfish in EFPC will continue under this plan. A more detailed outline of the bioaccumulation task is presented in Table 3.1. 
Table 3.1 Site designations, sampling period, and analyses to be performed for the Bioaccumulation Monitoring Task

\begin{tabular}{|c|c|c|c|c|}
\hline \multirow[b]{2}{*}{ Site } & \multirow[b]{2}{*}{ Sampling period } & \multicolumn{3}{|c|}{ Ánalyses } \\
\hline & & Mercury & PCBs & Metals \\
\hline EFK $24.8^{a}$ & May 1991-present & $X$ & $X$ & $X$ \\
\hline Lake Reality & May 1991 - present & $X$ & $X$ & \\
\hline EFK 23.4 & May 1985 - present & $X$ & $\mathrm{X}$ & \\
\hline EFK 18.2 & May $1985-$ present & $X$ & $\mathrm{X}$ & \\
\hline EFK 13.8 & May $1985-$ present & $X$ & $\mathrm{X}$ & \\
\hline EFK 6.3 & May $1985-$ present & $\mathrm{X}$ & $\mathrm{X}$ & \\
\hline $\mathrm{PCK}^{b} 1.6$ & Dec. 1987-present & $\mathrm{X}$ & & \\
\hline $\mathrm{CRK}^{c} 15.0$ & Nov. 1987-present & $\mathrm{X}$ & $X$ & \\
\hline Hinds Creek & May $1985-$ present & $\mathbf{X}$ & $X$ & $X$ \\
\hline
\end{tabular}

${ }^{\circ}$ Sampling reach at East Fork Kilometer 24.8 moved upstream slightly in December 1992.

${ }^{b}$ Poplar Creek kilometer.

${ }^{c}$ Clinch River kilometer.

\subsubsection{Contaminant Screening}

Screening of edible tissues of fish for metals (other than mercury) has not yielded evidence of contamination at any sites on the ORR, with the single exception of selenium and arsenic in Rogers Quarry. More sensitive measures, such as whole body analyses of herbivorous minnows, are a better alternative for evaluating ecotoxicological concerns associated with discharges. Such a sensitive indicator could be used to detect change over time. Metals analysis of fish filets will therefore be replaced by analyses of the whole-bodies of stonerollers. In 1995, an initial screening of stonerollers at three sites in EFPC showed that fish from EFK 24.8 contained the highest concentrations of most metals of potential concern (e.g. uranium, zinc). Three composite samples of stonerollers will be analyzed for a suite of metals at EFK 24.8 once yearly. 


\subsubsection{Contaminant Tracking}

Although mercury and PCB contamination in fish in EFPC have different sources and transport/transformation pathways, the temporal and spatial patterns of contamination are very similar. Therefore, tracking studies established in 1985 for each have utilized the same sites and fish. Redbreast sunfish will continue to be the primary species utilized in tracking studies. Redbreast sunfish sampling will be conducted twice yearly in EFPC to adequately evaluate changes in contamination over time; the number of fish collected at each site will be six.

Historically, largemouth bass were too uncommon to support a sustained monitoring effort; but their abundance has increased, at least in the upper third of the creek, to the point where a limited sampling of this species can be included. A good site for evaluating maximum concentrations in fish is LR because it provides suitable habitat for larger fish and is located close to the facility discharges. Depending on availability, four bass will be collected once yearly from two sites, LR and EFK 23.4.

Since 1986/1987, biota from waters downstream of EFPC have been monitored in conjunction with other BMAPs at the Oak Ridge National Laboratory (ORNL) and the K-25 Site to evaluate the relative contaminant contributions from DOE facilities. Monitoring of downstream areas will be reduced to two sites, one in lower Poplar Creek (PCK 1.6) and one site in the Clinch River downstream from all DOE facilities (CRK 15.0). Channel catfish will be used to monitor PCBs in the Clinch River and bluegill will be used to monitor mercury at both sites.

\subsubsection{Source Identification}

\section{Waterborne inputs of PCBs to EFPC}

Routine NPDES monitoring of discharges and receiving waters at the Y-12 Plant rarely detects PCBs despite the presence of PCBs in sediments and aquatic life in EFPC. Average PCB concentrations of approximately $1 \mu \mathrm{g} / \mathrm{g}$ in sunfish in EFPC above LR imply aqueous concentrations of less than $0.1 \mu \mathrm{g} / \mathrm{L}$, well below the NPDES reporting limit of $0.5 \mu \mathrm{g} / \mathrm{L}$. Measurements of PCBs in readily transported surface sediments are highest near the NSP, suggesting that waterborne PCBs originate upstream in the storm drain system. The application of passive PCB monitors (SPMDs, or semipermeable membrane devices) has been undergoing further development under this task. These devices provide a means of estimating timeaveraged aqueous PCB concentrations at various sites in EFPC and also in effluents and storm drains where aquatic organisms cannot survive. This subtask has investigated the application of SPMDs to estimating PCB concentrations in EFPC at various sites throughout its length; attempted to correlate

\section{3-4 Bioaccumulation Monitoring}


measures of waterborne PCBs with observed concentrations of PCBs in clams, fish, and sediments at those sites; and placed SPMDs at various discharges and sites within the subterranean storm drain system in an effort to locate specific sources. Identifying specific sources in the Y-12 Plant storm drain network will be the major focus of future efforts.

\subsection{STUDIES IN SUPPORT OF SITE-SPECIFIC WATER QUALITY CRITERION FOR MERCURY IN EFPC}

\subsubsection{Relationship Between Waterborne Mercury Species, Sediment-Associated Mercury, and Accumulation of Mercury in Fish}

Efforts to reduce the bioaccumulation of methylmercury in fish in EFPC are based on the assumption that most of the bioaccumulation of mercury by fish in the stream originates with waterborne inorganic mercury discharged by the Y-12 Plant. Concentrations of total mercury in creek water are thus assumed to be related to concentrations of methylmercury accumulated by fish, and reductions in total waterborne mercury should translate into reductions in mercury concentrations in fish. In the absence of adequate data to define this relationship on a site-specific basis for EFPC, discharge limits will need to be established based on the national water quality criterion, $0.012 \mu \mathrm{g} / \mathrm{L}$. Key assumptions of the national water quality criterion are clearly not met for mercury bioaccumulation in EFPC. Development of a site-specific criterion may allow Y-12 Plant discharges to be regulated in such a way that resources are most cost-effectively employed in controlling those factors that are of critical importance in determining the degree of mercury bioaccumulation in fish in EFPC.

Because the bioaccumulation of mercury involves a complex process in which inorganic mercury is converted to methylmercury by microorganisms and subsequently accumulated via the food chain pathway, the relationship between aqueous inorganic mercury concentrations and concentrations of mercury in aquatic organisms is not well known. Nevertheless, water quality criteria and standards enacted to prevent mercury accumulation use total aqueous mercury as the variable that must be regulated to prevent bioaccumulation. Therefore, it is essential to establish whether a predictive relationship exists between total aqueous mercury concentration and mercury bioaccumulation. In this subtask, key waterborne mercury species (such as total mercury; elemental, dissolved, and particle-associated inorganic mercury; and dissolved and particle-associated methylmercury) will be measured in water and fish in streams where mercury concentrations in fish are elevated above background concentrations. Particular emphasis will be made on measuring waterborne methylmercury in EFPC, where upstream remediation efforts should 
provide a unique opportunity to detect inputs from floodplain/sediment sources. Continued reductions in total waterborne mercury concentrations at the Y-12 Plant associated with ongoing abatement efforts and planned flow management should provide the opportunity to directly observe the response of mercury bioaccumulation and methylmercury generation to reduced precursor loading.

Mercury contamination of fish occurs in streams receiving effluents from the K-25 Site, Paducah Gaseous Diffusion Plant, and ORNL, as well as the Y-12 Plant. Measurements of mercury in fish and various aqueous mercury species will be made at several of these sites and also at other mercurycontaminated streams, such as the North Fork Holston River in Virginia/Tennessee. Results of those studies would help determine relationships between mercury bioaccumulation and aqueous precursor (methylmercury, dissolved inorganic mercury, etc.) concentrations at levels lower than can be attained in EFPC. 


\title{
4. Biological Indicators of Contaminant-Related Stress (Task 3)
}

\author{
S. M. Adams and M. S. Greeley, Jr.
}

\subsection{INTRODUCTION}

This task involves the use and application of various bioindicators of fish health and reproductive competence to evaluate the effects of water quality on the health of fish in EFPC. A suite of bioindicators has been used since the fall of 1985 and reproductive bioindicators have been used since 1988 to evaluate the health of an important indicator species, the redbreast sunfish, in EFPC as a component of the BMAP program (Loar et al. 1989; Loar et al. 1992a; Hinzman et al. 1995; Adams et al. 1989; Adams et al. 1992a).

Bioindicators have been used successfully to (1) evaluate the effect of water quality and other environmental variables on the health of individual fish populations in EFPC, (2) determine the effectiveness of past and ongoing remedial actions on these fish populations, and (3) aid in the identification of causative agents or mechanisms responsible for observed effects on aquatic ecosystem health. It is only through an understanding of such effects and mechanisms that reliable and defensible decisions can be made concerning the specific remedial actions to be undertaken and the application of the appropriate monitoring strategies for assessing the effectiveness of such actions.

The bioindicator approach used in the Y-12 Plant BMAP has also been used to evaluate ecosystem health and to aid in the evaluation of the effects of remedial actions on fish populations in other aquatic systems including (1) White Oak Creek as a component of the BMAP program (Ashwood 1994); (2) the Pigeon River in North Carolina and Tennessee, which is contaminated by pulp and paper effluents (Adams et al. 1992b); and (3) Hartwell Reservoir in South Carolina and Georgia, which is impacted by PCBs (Adams and Greeley 1991). Other systems currently being studied with the bioindicator approach are coastal areas of South Carolina influenced by paper mills and heavy industry, natural lakes on Cape Cod, Massachusetts, which are potentially contaminated with PAHs, and the Watts Bar Reservoir system including the Clinch River and Poplar Creek (Cook et al. 1993). Recent publications by Adams (1990a) and Adams et al. (1989) provide helpful guidance on the use and application of bioindicators in assessing the effects of contaminant-related stress on fish populations and other aquatic resources.

One of the primary advantages of the bioindicator approach in a comprehensive biological monitoring program is that it can be applied within a holistic or integrative framework to evaluate the effects of water 
quality and other environmental factors on overall fish health from both population and community perspectives (Adams et al. 1989; Adams 1990b). An integrative approach has several advantages over the use of individual response variables for investigating the relationship between fish health and environmental stressors. Stress effects on fish cannot be adequately evaluated by measurement of either a single stress response or even several responses displayed at only one level of biological organization because the sensitivity of fish to stress is not constant across all stressors (Heath 1987, 1990). Because no single variable or index is adequate for prediction of population and community-level changes (Capuzzo 1985), a few measurements cannot provide all of the integrative information necessary to understand the condition of a fish population or community (Cairns and Van der Schalie 1980).

In addition, consideration of too few response variables or classes of variables can complicate interpretation of the effects of environmental stressors on the integrity of biological systems. For example, single response measurements are often affected by variables that are difficult or impossible to control adequately, such as the overall environmental history, developmental state, reproductive condition, and nutritional status of the organism being studied (Sastry and Miller 1981). Furthermore, physiological compensation by organisms can affect interpretation of stress responses (Hazel and Prosser 1974).

Therefore, given the many limitations of using individual measurements and similar approaches to evaluate fish health, an integrative approach has been taken to more accurately reflect and evaluate the overall condition and health of an important fish population in EFPC. The Biological Indicators Task consists of two subtasks: (1) Bioindicators of Fish Health and (2) Bioindicators of Reproductive Competence. In addition, an integrative approach transcending subtask boundaries will continue to be applied, when feasible, to sampling designs and to the analysis of complementary types of data resulting from the two subtasks. Sections 4.2 and 4.3 provide a synopsis of previous sampling and results; Sects. 4.4 and 4.5 describe subtasks 1 and 2, respectively; Sect. 4.6 addresses sampling design; and Sect. 4.7 describes future monitoring and special studies.

\subsection{SYNOPSIS OF PAST AND PRESENT BIOLOGICAL INDICATORS TASK EFFORTS}

The Biological Indicators task was initiated in the Fall of 1985 when 12-15 adult male redbreast sunfish were sampled from each of 4 sites in EFPC, from Watts Bar Reservoir near Clinch River kilometer (CRK) 0.5, and from a reference site (Brushy Fork). During the first 2 years of the study (fall 1985-fall 1987), sampling was conducted on a seasonal basis (spring-summer-fall). Also during this time, a large

\section{4-2 Biological Indicators}


number and variety of bioindicators were tested and screened for future use. The only major change in sampling strategy during those two years was elimination of the Watts Bar Reservoir site in 1987, because redbreast sunfish were rarely found in this system and not enough individuals could be collected for meaningful statistical analysis.

In 1987, the number of male fish sampled per site was increased from 12-15 to $15-20$ in order to improve statistical confidence. A major change in sampling design occurred during the 1988 and 1989 period with the addition of two new reference streams, Hinds Creek and Paint Rock Creek (Fig. 1.2). Due to deteriorating water quality conditions, however, Paint Rock Creek was deleted from the sample plan in 1994. In 1988, female redbreast sunfish were collected as part of the reproductive effects assessment component of the fish health studies. Beginning in 1990, surface water samples from EFPC were tested with a fish embryo-larval toxicity test employing the newly fertilized embryos of the Japanese medaka (Oryzias latipes) as surrogates for the embryos of indigenous fish species. Except for these modifications, the sampling design of the Biological Indicators Task has remained relatively unchanged since 1989 in terms of the specific sites sampled, fish species collected, number of individuals collected per site, and the specific bioindicators parameters measured (Table 4.1).

Table 4.1. Site designations, sampling period, and sample form for the Biological Indicator Task

\begin{tabular}{cccc}
\hline Site & Sampling Period & Sample Form & Comments \\
\hline NSP $^{a}$ & 1992-present & Water $^{b}$ & \\
EFK $^{c} 23.4$ & 1990-present & Water & \\
EFK 23 & 1985-present & Fish $^{d}$ & \\
EFK 19 & 1985-present & Water, Fish & EFK 18 in 1985 \\
EFK 14 & 1985-present & Water, Fish & \\
EFK 6.3 & 1992-present & Water & EFK 5.3 in 1992 \\
Brushy Fork & 1985-present & Fish & Reference stream \\
Hinds Creek & 1989-present & Fish & Reference stream \\
\hline
\end{tabular}

North/South Pipes.

${ }^{b}$ Surface water samples for medaka embryo-larval tests.

${ }^{c}$ East Fork Poplar Creek kilometer.

${ }^{d}$ Redbreast sunfish (Samples may include fish from upstream of EFK 23). 


\subsection{SYNOPSIS OF PAST RESULTS OF THE BIOLOGICAL INDICATORS TASK}

A summary of the major finding for the Biological Indicators task from 1986 to 1994 indicates that (1) a downstream gradient exists in the health of fish in EFPC, with individuals from the upper reaches exhibiting the poorest health and fish from the lower sites exhibiting the best health. This downstream gradient in health appears to be correlated with contaminant loading of PCBs and mercury in sunfish; (2) fish in EFPC continue to be affected by environmental stressors in this systems even though effects are less severe than those observed during the first 4-5 years of monitoring; (3) the health status of redbreast sunfish continues to improve, especially in the upper half of the stream, apparently in response to remedial actions within the EFPC watershed; (4) most home-range movements of five sunfish species are less than $100 \mathrm{~m}$, making these species, and especially redbreast sunfish, useful for environmental monitoring studies; and (5) mercury may be the major contaminant causing physiological and biochemical stress in sunfish, particularly at the upper sites in the stream.

Redbreast sunfish have been observed to consistently begin spawning approximately 1 month earlier in EFPC than in area reference streams. This pronounced lengthening of the breeding season is almost certainly due to the higher and more stable water temperatures in upper EFPC as a result of discharges from the Y-12 Plant. The higher water temperatures in upper EFPC may be contributing to the continued absence of many historical fish species from these reaches of the stream.

Although there is little evidence for acute reproductive failure in any stretch of EFPC downstream of NHP or LR, except in the case of female redbreast sunfish collected from just below NHP in Spring 1988, the reproductive competence of fish in EFPC differs quite markedly from that of fish in reference streams. For example, oocyte atresia (injury or death of eggs) is evident at EFK 23 and at other sites upstream of $\mathrm{LR}$, possibly due to elevated water temperatures in the upstream reaches of EFPC, direct chemical toxicity to the developing oocytes, and/or bioenergetic factors such as altered food availability. Also, fecundity is generally higher and more variable in EFPC than in reference streams.

Fertilized eggs of the Japanese medaka experience a high percentage of developmental failure when exposed to EFPC water during embryonic and early fry development. Direct chemical toxicity to developing embryos and fry could help explain the continuing absence from upper EFPC of reproducing populations of several pollution-sensitive fish species native to this area. The adverse effects of water from upper EFPC on fish embryos were less pronounced in more recent tests, suggesting that remedial activities 
at the Y-12 Plant are contributing to a measurable improvement in water quality in the upper reaches of EFPC.

\subsection{BIOINDICATORS OF FISH HEALTH SUBTASK (SUBTASK 3a)}

\subsubsection{Bioindicator Response Measures}

The original BMAP sampling plan for the Y-12 Plant included measurement of a wide range of indicators at each of several levels of biological organization. Because bioindicator-type studies had not been conducted at the time of issuance of the original plan, the basic strategy of sampling at that time was to measure a suite of indicators and responses representative of several levels of biological organization. After several years of screening and evaluation of the bioindicator data, a subset of the most cost-efficient bioindicators was chosen for future monitoring. The principal functional bioindicator groups included in the remaining subset are (1) detoxification enzymes, (2) metabolic dysfunction indicators, (3) condition indices, (4) bioenergetic function parameters, (5) indicators of feeding and nutrition, (6) reproductive responses, and (7) population-level indices. The specific indicators measured in each group are discussed below.

\subsubsection{Indicators of Contaminant Exposure}

The activity or levels of liver detoxification enzymes are often used to indicate exposure to various contaminants, such as PCBs, PAHs, and pesticides (Chambers and Yarbrough 1976, Stegeman and Klopper-Sams 1987). With some contaminants such as PAHs, detoxification enzymes may be viewed as a diagnostic indicator for more serious effects on organisms, because detoxification enzyme activity is required for activation to the ultimate carcinogens. The lag time between exposure to a contaminant and the biological response is typically short (hours-days), with the response generally persisting throughout the exposure and for some time thereafter (days-weeks). As a proven indicator of contaminant exposure, the activity of EROD (ethoxyresorufin O-deethylase) will continue to be measured in the liver of fish sampled from EFPC and the reference sites. The concentration of microsomal protein in hepatic tissue will also be quantified to serve as a standard for reporting EROD activity and also to indicate possible microsomal proliferation due to contaminant exposure. EROD and microsomal protein appear to be the most useful general indicators of toxicant exposure in bioindicator studies conducted in other aquatic systems as well (Loar et al. 1991, 1992b; Adams and Greeley 1991; Adams et al. 1992a, 1992b). 


\subsubsection{Indicators of Metabolic Dysfunction}

Various types of biochemical assays of the blood can be used to indicate metabolic dysfunction in critical organs such as the liver, kidney, and gills. Circulating concentrations of biochemicals associated with the General Adaptation Syndrome (GAS) of Selye (Selye 1950) are a function of their secretion into and clearance from the blood. Indicators of cell/tissue/organ dysfunction represent a wide variety of assays including serum enzymes such as lysosomes and transaminases, electrolyte homeostasis such as $\mathrm{Na}^{++}$and $\mathrm{K}^{+}$, carbohydrate and lipid metabolism (glucose and triglycerides), endocrine related hormones (corticosteriods, catecholamines), and reproductive hormones (estradiol, testosterone). Excluding reproductive hormones, which are addressed in Subtask $3 \mathrm{~b}$ on reproductive indicators, we will be measuring several organ dysfunction indicators in the blood including (1) serum albumin, an important component of both osmotic regulation and the binding and transport of compounds such as fatty acids and hormones and a general indicator of liver dysfunction; (2) creatinine, an indicator of kidney damage or malfunction; (3) the transaminase enzymes alanine aminotransferase (ALT) and aspartate aminotransferase (AST), which are used as indicators of liver damage, reflecting cirrhosis or obstructive jaundice; and (4) blood urea nitrogen (BUN), an indicator of gill dysfunction.

\subsubsection{Indicators of Bioenergetic Function and Lipid Dynamics}

Organisms exhibit numerous energetic responses when responding to toxicant-induced stress. Some of these responses can be directly related to the GAS (Selye 1950), which is based on the concept that energy is required to maintain homeostasis. Other responses are the direct result of toxicants interfering with key metabolic pathways. Acute responses, which are generally hormonally controlled, are considered to be the initial response to the stressor and often involve the increase of energy-related substrates in the plasma/hemolymph. Chronic stress can initiate compensatory physiological adjustments whereby changes in energy metabolism demand the majority of an organism's energy expenditure, which usually results in reduced growth or reproduction because of increased metabolism. Consequently, a comparative assessment of the energy status of an organism can be indicative of its overall condition. The energy status of fish sampled from EFPC and reference streams will be assessed by measuring various components of energy reserves and dynamics in fish, including blood triglyceride and visceral lipid stores. 


\subsubsection{Condition Indices}

Various indices have been used to evaluate the condition or well-being of fish. The use of condition indices provides a method for "bridging the gap" between biochemical and physiological alterations at the cell and tissue level and the resultant structural and functional changes at the organism and population level. The major advantage of using condition indices over other bioindicators for evaluating environmental stress is that they provide a relatively simple, cost-effective, and rapid indication of how well fish are coping with their environment.

Condition indices, and particularly those that are representative of the whole organism, can be used to relate the consequences of biochemical and physiological alterations in the organism with observed changes in the individual and in the population. Many of these indices can serve as early warning signs that signal departures from normal within the population. If such changes are detected, then more specific investigations may be conducted. The condition indices to be measured in this subtask are based on the ratios among morphological and anatomical features of fish. These include (1) the traditional condition factor which reflects the "plumpness" or general well-being of fish (LeCren 1951); (2) the liver-somatic index, which is indicative of both energy storage (Heidinger and Crawford 1977) and exposure to toxicants (Fletcher et al 1982); (3) the visceral-somatic index, which indicates fat storage (Adams and McLean 1985); and (4) the spleno-somatic index, which can be used to evaluate disease or immune system problems (Goede and Barton 1990).

\subsubsection{Indicators of Nutritional Status and Feeding}

The nutritional status of organisms is important for interpreting and evaluating the nature of stress responses to contaminants. Environmental factors, such as food and habitat availability, can modify or modulate the responses of organisms to stress (Niimi 1990, Adams et al. 1992a). As indicators of feeding intensity (which in a general way reflects food availability), the percent of the stomach and intestine containing food and the size and the color of the gall bladder will be determined. The nutritional status of fish will be assessed based on the visceral-somatic index, proportion of viscera composed of neutral fats, and triglyceride levels in the blood.

\subsubsection{Population-Level Indicators}

The principal population-level indicators provide information on the growth and production potential of a species and also on recruitment or reproductive success. Growth is an ultimate expression of fish 
health or condition because it integrates all the biotic and abiotic variables acting on an organism and reflects secondary impacts of chronic stress (Larkin 1978, Adams and McLean 1985). The primary population-level indicators that will be measured in sunfish collected from EFPC and reference streams are growth (weight and length at age) and size frequency distributions.

\subsection{BIOINDICATORS OF REPRODUCTIVE COMPETENCE SUBTASK (SUBTASK 3b)}

\subsubsection{Goals}

Reproduction is widely considered to be one of the most critical life functions affected by chronic contaminant-related stress (Birge et al. 1985). The ability to successfully reproduce is essential for the establishment and continued maintenance of viable fish populations. In addition, certain reproductive processes, including egg production (Suter et al. 1987) and embryonic development (Adams and Greeley 1993), are among the most sensitive life stages to environmental toxicants. Reproduction (propagation) of aquatic life is also a classified use of EFPC as determined by the state of Tennessee. Therefore, the potential for fish reproduction in EFPC to be adversely affected by Y-12 Plant operations will be examined in a separate subtask of the Biological Indicators Task.

One goal of Subtask $3 b$ is to characterize the reproductive competence of fish populations in EFPC downstream of the Y-12 Plant and to compare the reproductive competence of these populations with fish populations in reference streams. This goal will be addressed through a comparison of selected reproductive parameters in key fish species at several EFPC sites and at a number of reference sites. When feasible, reproductive measures will be correlated with the levels of contaminants in fish and the relevant bioindicator responses, as measured in the bioindicators of fish health subtask.

Another goal Subtask $3 b$ is to relate reproductive bioindicator responses measured in adult fish from EFPC to the actual recruitment success of select species, as estimated from stream surveys of young-ofthe-year fish conducted in Subtask $4 \mathrm{c}$ after the spawning season. A third goal is to examine the potential adverse effects of EFPC water on fish embryonic and larval development by exposing fish embryos from laboratory stocks to water collected from EFPC downstream of major plant outfalls and examining subsequent developmental responses. 


\subsubsection{Reproductive Response Parameters}

A number of potential environmental contaminants have been shown to adversely affect fish reproduction in laboratory tests. For example, PCBs (which are typically present in fish sampled from EFPC) are reported to have diverse effects on fish reproduction via alterations in adult reproductive condition (Freeman and Idler 1975, Sivarajah et al. 1978), embryonic and fry developmental success (Halter and Johnson 1974, Nebeker et al. 1974, Mauck et al. 1978, Ankley et al. 1991), and fry survival (Halter and Johnson 1974, Nebeker et al. 1974, Schimmel et al. 1974, Mauck et al. 1978).

\subsubsection{Adult Fish}

Lipophilic compounds, including the PCBs and dioxins, tend to accumulate in tissues of the body which have a relatively high fat content (i.e., the ovaries of organisms with yolk-laden ova). Possibly, as a result of their localized accumulation in such critical reproductive tissues, these compounds are known or suspected to exert many of their physiological and/or ecological effects through direct effects on the reproductive process (Halter and Johnson 1974, Nebeker et al. 1974, Schimmel et al. 1974, Freeman and Idler 1975, Sivarajah et al. 1978, Mauck et al. 1978, Ankley et al. 1991). For each EFPC and reference site, fish gonadal condition will be assessed by calculating the gonadal-somatic index (GSI, the percentage of total body weight contributed by the gonad) and by visual examination of gonadal appearance (color, shape, and, in females, gross appearance of the oocytes). Estimates of oocyte abundance and oocyte developmental stages will be determined for females. Particular emphasis will be placed on determining fecundity through enumeration of oocytes in the developing clutches, quantifying oocyte atresia and reabsorption, and obtaining a value for total vitellogenic cocytes (an indirect measure of the bioenergetic effort expended during the reproductive process). One testis from each male will be examined histologically for the occurrence of obvious developmental abnormalities in the spermatogenic stages.

The P-450 enzyme system functions in the metabolism of steroid hormones as well as chemical toxicants (Ryan et al. 1982, Haake-McMillan and Safe 1991). To again use PCBs as an example, this class of environmental contaminant has been reported to depress steroid metabolism in rats (Miranda et al. 1990), stimulate the metabolism of testosterone by trout testicular tissue (Freeman and Idler 1975), and cause a significant reduction in the plasma levels of both androgens and estrogens in trout and carp (Sivarajah et al. 1978). Female English sole from environmental sites heavily contaminated by PCBs were observed to have significantly lower plasma estradiol levels than fish from less contaminated sites (Johnson et al. 1988). Decreasing trends in both estradiol and testosterone were observed for female largemouth 
bass inhabiting a PCB-contaminated reservoir (Adams and Greeley 1991). For this plan, plasma levels of estradiol and testosterone will be measured in female fish, and 11-ketotestosterone and testosterone in male fish (if sufficient plasma is available for these assays following completion of the various plasma assays associated with the bioindicators of fish health subtask).

\subsubsection{Juvenile Fish}

Length-frequency measurements and relative abundance during a series of timed electro-fishing runs will constitute the primary assessment criteria for surveys of young-of-the-year fish to be conducted in Subtask $4 c$.

\subsubsection{Embryo-Larval Tests}

One potential cause for the reproductive failure of fish populations, in addition to observable problems with adult reproductive activities, is the failure of spawned eggs to develop properly into new reproductive cohorts. Assessment criteria for the fish embryo-larval testing portion of this reproductive effects assessment will include hatching success, time-to-hatch, the incidence of developmental abnormalities during both embryonic and early larval development, and the survival of embryos and yolksac larva.

\subsection{SAMPLING DESIGN FOR THE BIOLOGICAL INDICATORS TASK}

The principal sampling design components of the Biological Indicators Task are the species to be collected, sampling sites, sampling frequencies, and the specific responses to measured. Response measurements are discussed in Sects. 4.4 and 4.5.

\subsubsection{Species to be Sampled}

To assure continuity of results with previous fish health and reproductive studies in EFPC, redbreast sunfish will continue to remain the primary target species for this task. The Japanese medaka (Oryzias latipes), a small fish native to Southeastern Asia, will be the primary fish species utilized in the embryolarval testing portion of the reproductive subtask. Medaka are an increasingly popular aquatic species for both carcinogenicity and toxicity testing of chemicals in the laboratory. This fish has several advantages for use in developmental toxicity testing, including its ease of maintenance in the laboratory, the reliability with which eggs can be obtained for testing purposes on a daily basis year-round, its long embryonic period with

\section{4-10 Biological Indicators}


a resulting increase in sensitivity to many environmental contaminants, and the clarity of the embryo (which allows easy observation of developmental abnormalities arising prior to hatch). Medaka have been employed in the BMAP for examining the effects on fish embryo-larval development of water from EFPC and White Oak Creek on the ORR and in the Clinch River Environmental Restoration Program for examining the developmental toxicity of water from Poplar Creek and the Clinch River.

\subsubsection{Sites}

Of the four sites in EFPC that have been sampled at least annually since 1986, three will continue to be sampled annually under this plan for both the fish health and reproductive competence subtasks. These sites are (1) upper EFPC between EFK 24.0 and 22.5, (2) EFK 19, downstream of the Highway 95 bridge; and (3) EFK 14, above the ORWTF. At least $200 \mathrm{~m}$ of stream will be sampled at each site to obtain the required number, size, and sex ratio of fish. Water samples to be tested for toxicity to medaka embryos will be collected from these same general sites in the downstream reaches of EFPC and from sites in the upstream reaches of EFPC (EFK 23.4 and NSP).

In addition to these three primary EFPC sites, at least two reference streams, Hinds Creek and Brushy Fork, will also continue to be sampled on an annual basis. A third reference stream may be occasionally monitored as a check on the health status of the Hinds Creek and Brushy Fork fish. The sampling design for the reference sites is subject to modification (additional sites may be added) if necessary to meet changing requirements of the task. For example, over the past two years, sunfish have been increasingly difficult to obtain at the three primary reference streams, possibly because of the increased siltation observed in these systems. If degradation of these streams continues, new reference streams may need to be added as replacements for the present sites.

\subsubsection{Sampling Frequency}

The results of previous bioindicator studies conducted in a variety of aquatic systems including EFPC (Loar et al. 1992a; Hinzman et al. 1993, 1995; Adams et al. 1992a, 1992b; Adams and Greeley 1991) have demonstrated that for most bioindicator responses, annual sampling is adequate for evaluating the effects of water quality and other environmental variables on fish health. Indeed, many bioindicators-including histopathological parameters-various population-level indices, and reproductive responses, are integrative in nature and reflect the effect of environmental variables over long time periods (Adams 1990b). Thus, fish sampling for both the fish health and reproductive competence subtasks of this 
task will continue to be conducted annually in EFPC and the reference streams. Embryo-larval tests of water from EFPC will be conducted at least biannually (Table 4.1).

\subsection{SPECIAL MERCURY AND FISH DEVELOPMENT STUDIES}

Mercury and other metals could also contribute to the observed toxicity of EFPC water to developing fish embryos. Medaka embryos are known to bioconcentrate mercuric compounds, with bioconcentration factors for mercuric chloride ranging from 1590 to 2677 (Heisinger and Green 1975). Mercuric chloride is also reported to have non-lethal teratogenic effects on medaka embryos at concentrations ranging from 10 to $15 \mathrm{ppb}$, and lethal effects at concentrations exceeding $20 \mathrm{ppb}$ (Heisinger and Green 1975). Preliminary toxicant identification evaluations on water samples from EFPC and laboratory experiments with medaka embryos exposed to varying dosages and species of mercury and other metals will be performed in order to address this question. 


\section{Instream Ecological Monitoring (Task 4)}

\subsection{PERIPHYTON (SUBTASK 4a) (W. R. Hill)}

Periphyton (attached algae) forms the base of the food web in streams. It uses sunlight to convert dissolved inorganic carbon and other plant nutrients into biomass that is grazed by invertebrates and some fish (e.g., stoneroller minnows). Periphyton is a useful component to measure impacts because of its (1) importance to higher trophic levels, (2) sensitivity to both enrichment and contaminants, (3) effect on water chemistry, and (4) potential significance in the sorption and transfer of waterborne contaminants (Boston et al. 1991, Stewart et al. 1993). Periphyton in EFPC has been examined as part of the Y-12 BMAP plan for six years. Five sites on EFPC and one reference site on BF have been used to assess Y-12 Plant effects on periphyton biomass (chlorophyll $a$ ), photosynthesis, and taxonomic composition. Nutrients (dissolved phosphorus and nitrogen) have been measured as part of the periphyton monitoring at these sites. Several special studies, such as the measurement of metals in EFPC periphyton, were also undertaken.

The results of the BMAP studies indicate that operations at the Y-12 Plant have impacted periphyton communities. The effects of the Y-12 Plant on nutrients and streamside shade also influence periphyton in EFPC. Nutrients in EFPC were higher than would be expected (compared with other streams and groundwater emanating from Chestnut Ridge), implicating the Y-12 Plant as a significant source of nitrogen and phosphorus. These elevated concentrations of nutrients undoubtedly contribute to the relatively high levels of primary production at unshaded sites in EFPC. Periphyton biomass (chlorophyll $a$ ) generally decreased in a downstream direction, probably as a result of increasing shade from streamside vegetation. Upstream sites (EFKs 24.4, 23.4, and 13.8) have little shade compared with downstream site EFK 6.3 and the reference site (BFK 7.6). The projected increase in streamside vegetation (e.g., trees) at the two upper sites (EFKs 24.4 and 13.8) will decrease periphyton production at these sites.

Metal concentrations in periphyton were very high at upstream EFPC sites. Mercury, for example, was present at over $600 \mathrm{ppm}$ dry mass at EFK 24.4. Other metals of concern that were found at elevated concentrations at upstream sites were cadmium, copper, nickel, zinc, and silver. Metal concentrations in periphyton generally decreased with distance downstream of the Y-12 Plant, a trend consistent with the downstream decline of contaminant concentrations in EFPC fish (Hinzman et al. 1993), indicating that the Y-12 Plant was the source of the metals. 
Monitoring of periphyton biomass (chlorophyll $a$ ) and photosynthesis will continue at approximately quarterly intervals (Table 5.1). Emphasis will be placed on the detection of remediation-related changes in the periphyton. Future work will also include monitoring of contaminant burdens in periphyton. Many metals are accumulated to higher levels in periphyton than in upper trophic levels (Hill et al., in press), so periphyton will be used to assess changes in metal levels that occur through remediation.

The trophic consequences of the impacts on periphyton will be emphasized more in future work. There is currently little empirical information useful for interpreting how changes in periphyton production, resulting from Y-12 Plant operations, affects the growth and propagation of higher trophic levels.

\subsubsection{Methods}

\section{Monitoring biomass and photosynthesis}

Chlorophyll $a$ and single-irradiance photosynthesis will be measured every 3 months at three EFPC sites (EFKs 24.4, 23.4, and 6.3) and one BF site (BFK 7.6). These sites have been used extensively in the past, and maintaining the monitoring at these sites will provide the continuity necessary for the detection of environmental changes in EFPC. Methods for assessing chlorophyll $a$ and photosynthetic rates will be the same as used previously: four small rocks from each site will be collected, returned to the laboratory, and assayed for chlorophyll $a$ and ${ }^{14} \mathrm{C}$ uptake [at ca. $350 \mu \mathrm{mol}$ quanta $\mathrm{m}^{-2} \mathrm{~s}^{-1}$ (Hinzman et al. 1993)].

Table 5.1. Sites sampled in the Periphyton Community Task

\begin{tabular}{ccc}
\hline Site & $\begin{array}{c}\text { Chlorophyll and } \\
\text { photosynthesis }\end{array}$ & Metal analysis \\
\hline EFK $^{a} 24.4$ & $\mathrm{X}$ & $\mathrm{X}$ \\
EFK 23.4 & $\mathrm{X}$ & $\mathrm{X}$ \\
EFK 18.4 & & $\mathrm{X}$ \\
EFK 6.3 & & $\mathrm{X}$ \\
$\mathrm{BFK}^{b}$ 7.6 & $\mathrm{X}$ & \\
\hline
\end{tabular}

${ }^{a}$ East Fork Poplar Creek kilometer.

${ }^{b}$ Brushy Fork kilometer. 


\section{Contaminant burdens}

Metals in EFPC periphyton will be measured once a year in samples from EFK 24.4, EFK 23.4, EFK 18.4, and EFK 6.3. In addition, metal concentrations will be compared in shaded and unshaded periphyton at upstream EFPC sites (EFK 24.4 and EFK 23.4) in order to predict effects of riparian revegetation.

\subsection{BENTHIC MACROINVERTEBRATES (SUBTASK 4b) (J. G. Smith)}

\subsubsection{Background}

Results from the first year of the EFPC BMAP (i.e., June 1985-May 1986) showed that the benthic macroinvertebrate community was impacted at all six sites studied (Loar et al. 1992a). The macroinvertebrate community at the site closest to the Y-12 Plant (EFK 24.4) was the most impacted, but improvements were evident with increasing distance from the Y-12 Plant. The macroinvertebrate community at EFK 13.8 was the least degraded (e.g., highest taxonomic richness), but compared with the reference site (BFK 7.6) it still exhibited characteristics of impact. A similar longitudinal pattern was observed in EFPC for years two and three of the BMAP, therefore, showing that changes were small over this three-year period (Smith and Dickinson 1995).

A major source of colonizing organisms in streams following a disturbance is drift from unimpacted upstream reaches (Wallace et al. 1986; Williams and Hynes 1976, 1977). Because a depauperate macroinvertebrate community exists in the headwaters of EFPC, drift is not likely to serve as a major mechanism for recolonization in the initial stages of upper EFPC's recovery process. Thus, it should take longer to detect a response in the invertebrate community to improvements in water quality than if there been an unimpacted area upstream of the Y-12 Plant.

In 1988, an in situ bioassay was developed in which an endemic clam (Sphaerium fabale) was used as a surrogate for macroinvertebrate community conditions. The intent of the bioassay was to provide a method to detect changes in water quality more rapidly in an environment such as that present in upper EFPC. Clams were placed in cages at study sites in EFPC and reference sites, and then their growth and survival were followed (Smith and Tolbert 1993; Smith and Dickinson 1995; J. G. Smith, ORNL/ESD, unpublished data). The results of several studies conducted since 1988 suggest that water quality improved with increasing distance from the Y-12 Plant. In the three studies that included EFK 24.4, growth of clams at this site was negligible and all clams were dead within $\leq 75$ days. At EFK 23.4 growth was suppressed 
compared with reference sites in all eight studies. Survival of clams at EFK 23.4 varied among studies. Mortality was rapid at EFK 23.4 in studies conducted in 1988, 1989, and 1991 but were comparable to reference sites in studies conducted in the summer and fall of 1990 and in 1993 . The variability in survival of clams at EFK 23.4 suggested that conditions leading to mortality at this site were intermittent. Survival of clams at EFK 13.8 was always high, but growth was suppressed when compared with reference sites.

\subsubsection{Benthic Macroinvertebrate Monitoring Task Plan}

\section{Sample Collection and Analysis}

Five quantitative benthic macroinvertebrate samples will be collected biannually (April and October) from randomly selected locations within a designated riffle at each sampling site (Table 5.2). Four sites will be sampled in EFPC (EFKs 24.4, 23.4, 18.7, and 13.8), and one site will be sampled in each of two reference streams (BFK 7.6 and HCK 20.6; Fig. 1.2). Samples will no longer be collected from EFK 6.3 because it is felt that this site provides little information on the area of the stream where most emphasis and interest exists (i.e., upper EFPC). Samples will be collected with a modified Hess sampler $\left(0.1 \mathrm{~m}^{2}\right)$ fitted with a $363-\mu \mathrm{m}$-mesh collection net. Each sample will be preserved in $\sim 80$ percent ethanol that will be replaced with fresh 80 percent ethanol within 1 week after collection. Details of the procedures that will be followed in the collection and maintenance of samples are in Smith and Smith (1995).

Table 5.2. Sites sampled for the Benthic Macroinvertebrate Community Studies Task

\begin{tabular}{|c|c|c|}
\hline Site & Sample Period & Comments \\
\hline $\mathrm{EFK}^{a} 24.4$ & Jun. 1985 to present & \\
\hline EFK 23.4 & Jun. 1985 to present & \\
\hline EFK 18.7 & Oct. 1989 to present & Site added to replace EFK 18.2 \\
\hline EFK 13.8 & Jun. 1985 to present & \\
\hline $\mathrm{BFK}^{6} 7.6$ & Jan. 1986 to present & \\
\hline $\mathrm{HCK}^{c} 20.6$ & Oct. 1987 to present & \\
\hline
\end{tabular}

${ }^{a}$ East Fork Poplar Creek kilometer.

${ }^{b}$ Brusy Fork kilometer.

${ }^{c}$ Hinds Creek kilometer. 
Samples from all sites except EFK 18.7 will be processed. Samples collected from EFK 18.7 will be stored and maintained in a chain-of-custody storage facility following procedures outlined in Smith and Smith (1995). These samples will be processed only if the data will be beneficial for assessing the effectiveness of remedial actions or abatement activities. The remaining samples will be processed in the laboratory where the organisms will sorted from the sample debris (e.g., gravel and detritus), identified to the lowest practical taxonomic level, and enumerated. Identification of oligochaetes (aquatic worms) will be to class only, and chironomids will be identified to subfamily and tribe only. Details of the laboratory procedures that will be followed are given in Smith and Smith (1995).

Data will be managed and analyzed on a personal computer or workstation with Statistical Analysis System (SAS) software and procedures (SAS 1985a,b). Analyses will include, but not necessarily be limited to, general descriptive statistics and parametric statistics (e.g., analysis of the variance) to evaluate trends in temporal and spatial patterns that could be associated with abatement activities or remedial actions. A partial list of metrics to be considered includes density, total taxonomic richness, and richness of the pollution sensitive Ephemeroptera, Plecoptera, and Trichoptera (EPT richness).

\section{Special Studies}

In situ bioassays using the clam $S$. fabale will be conducted approximately every two years. The bioassays will be used to help evaluate water quality, and, where possible, the effectiveness of abatement actions. The procedures followed for this assay are described in Smith and Dickinson (1995).

\subsection{FISH COMMUNITY STUDIES (SUBTASK 4c) (M. G. Ryon)}

Fish population and community studies can be used to assess the ecological effects of changes in water quality and habitat. These studies offer several advantages over other indicators of environmental quality (Karr 1987) and are especially relevant to assessment of the biotic integrity of EFPC. Monitoring of fish communities has been used within BMAP for receiving streams at ORNL (Loar et al. 1991), K-25 Site (Loar et al. 1992b, Ryon 1993a), Paducah Gaseous Diffusion Plant (Ryon 1994a), the Portsmouth facility (Ryon 1994b), as well as streams associated with the Y-12 Plant (Loar et al. 1989, Ryon 1992a, Southworth et al. 1992), with some programs operational since 1984. Changes in the fish communities in these systems have indicated recovery (Ryon 1993b, 1994c) as well as documented impacts (Ryon 1994a, 1993c). 
Sampling of the fish community in EFPC under the initial BMAP began with quarterly samples in 1985 (Loar et al. 1992a) and continued from 1986 with spring and fall samples. The primary objectives of this sampling were to characterize the fish communities in the stream and to identify impacts associated with Y-12 Plant operations. The objectives of the fish community task under the current plan are to continue monitoring the fish community structure and conduct supplemental studies as needed.

Data obtained from 1985 to 1993 for EFPC documented a substantial impact on the fish community in the vicinity of the Y-12 Plant and downstream more than $5 \mathrm{~km}$ into the city of Oak Ridge (Loar et al. 1992a, Ryon 1993b). However, the monitoring also detected a gradual recovery of the fish communities in EFPC, beginning with the most downstream sites and slowly progressing through time to sites closer to the Y-12 Plant. The degree of impact and the pattern of recovery are supported by changes in species richness (Fig. 5.1), species abundance (Fig. 5.2), and species composition. In the vicinity of the $\mathrm{Y}-12$ Plant, recovery has been dominated by more tolerant species that have increased in density (up to 100 fold) and biomass (up to 7 fold). The composition of this community has also become more complex, with an increase in species richness and occasional occurrences of intolerant species. At downstream sites, there was a similar but smaller increase in density and biomass. However, the increase in species richness was proportionally greater at downstream sites than at sites closer to the Y-12 Plant, with more intolerant species, more benthic insectivores, and more sensitive species (e.g., darters and suckers). Despite the continual improvement in overall species richness, the number of intolerant and sensitive species remains below levels in similar-sized reference streams. This deficiency indicates that there is the potential for further recovery of fish communities in EFPC. Efforts in the revised BMAP will focus on this recovery and try to differentiate impacts impending further recovery.

In November 1988, NHP was drained, capped, and replaced by LR, a lined-basin. Upper EFPC was routed around the NHP cap to LR in a concrete diversion channel and flowed out of LR through a v-notch weir. The design of the weir allowed fish to access LR and upper EFPC and led to established fish communities in both the basin and the stream above it (Fig. 5.3).

As a result of the change in access to upper EFPC through LR, fish were in closer contact with effluents from the Y-12 Plant, and more frequent fish kills occurred. During 1988 to 1993, chlorinated water released to upper EFPC produced a chronic kill resulting in a low ( $<10$ dead fish/day) but nearly continuous level of mortality (Etnier et al. 1995). Additional releases or episodes produced more acutetype kills, often with high mortality over a few days (up to 350 fish in a day). Dechlorination of two major

\section{5-6 Instream Ecological Monitoring}



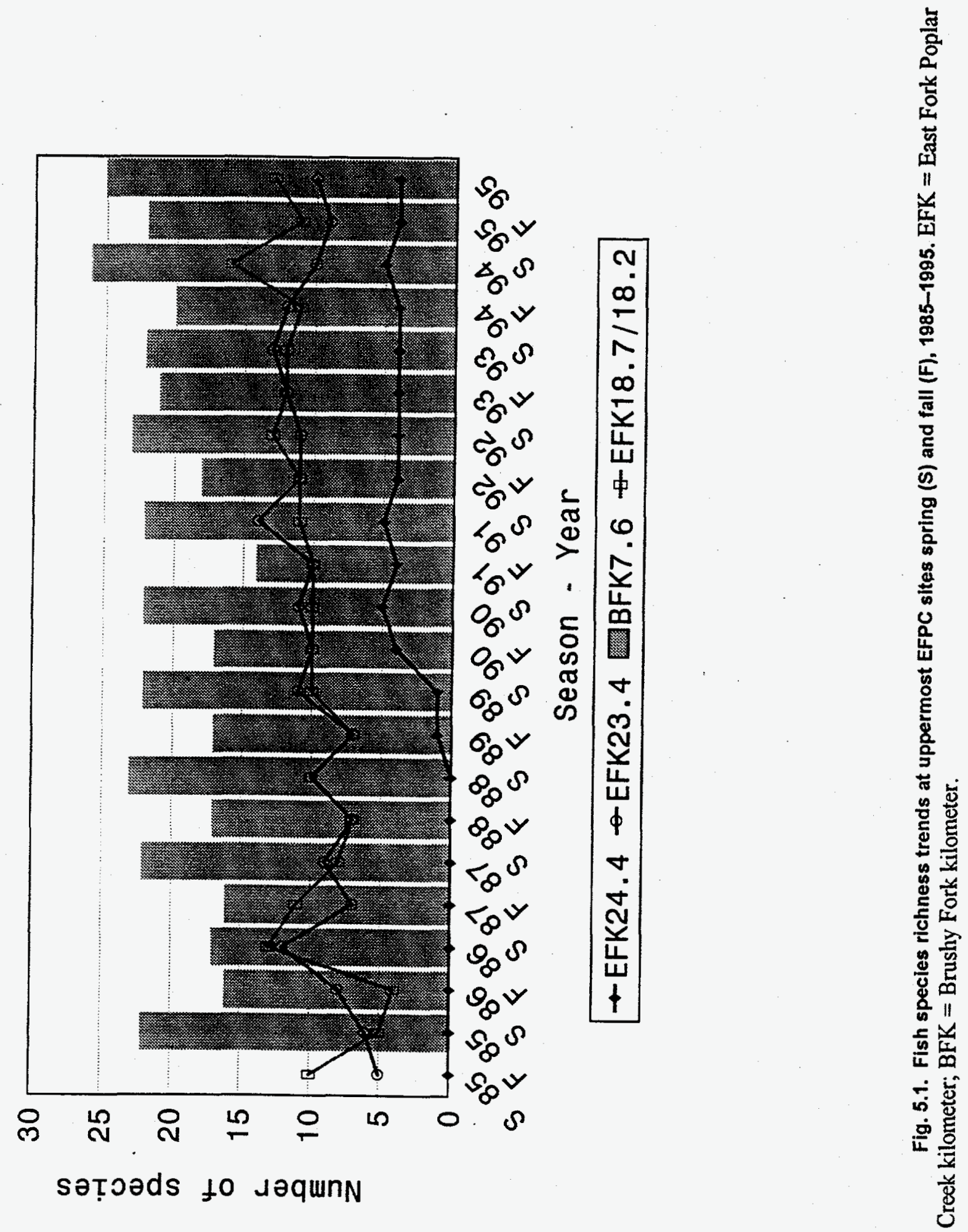

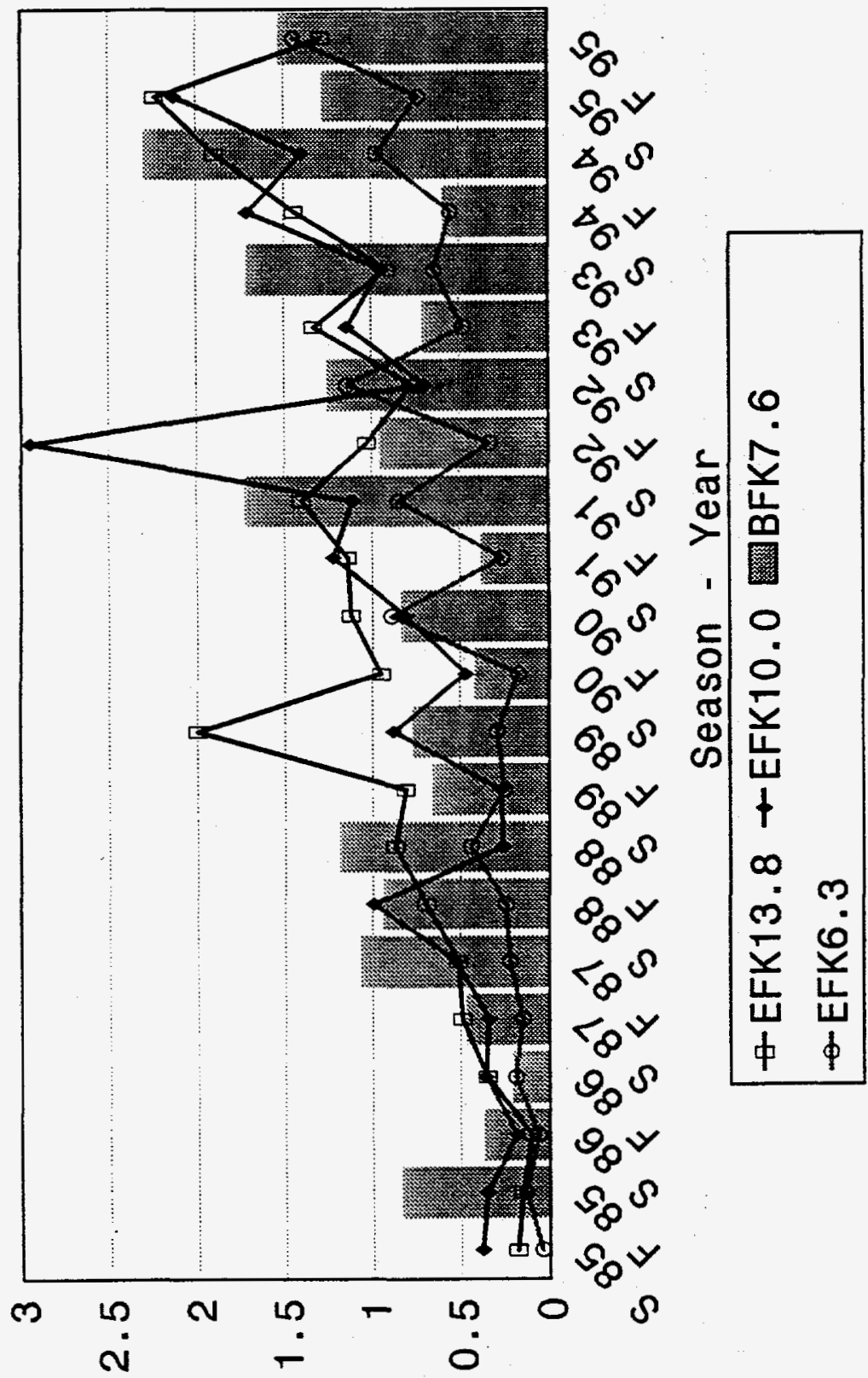

(w bs ləd usțł) KłṬsuəa

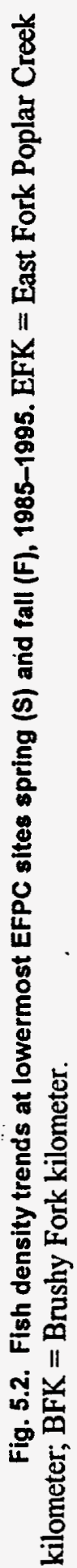



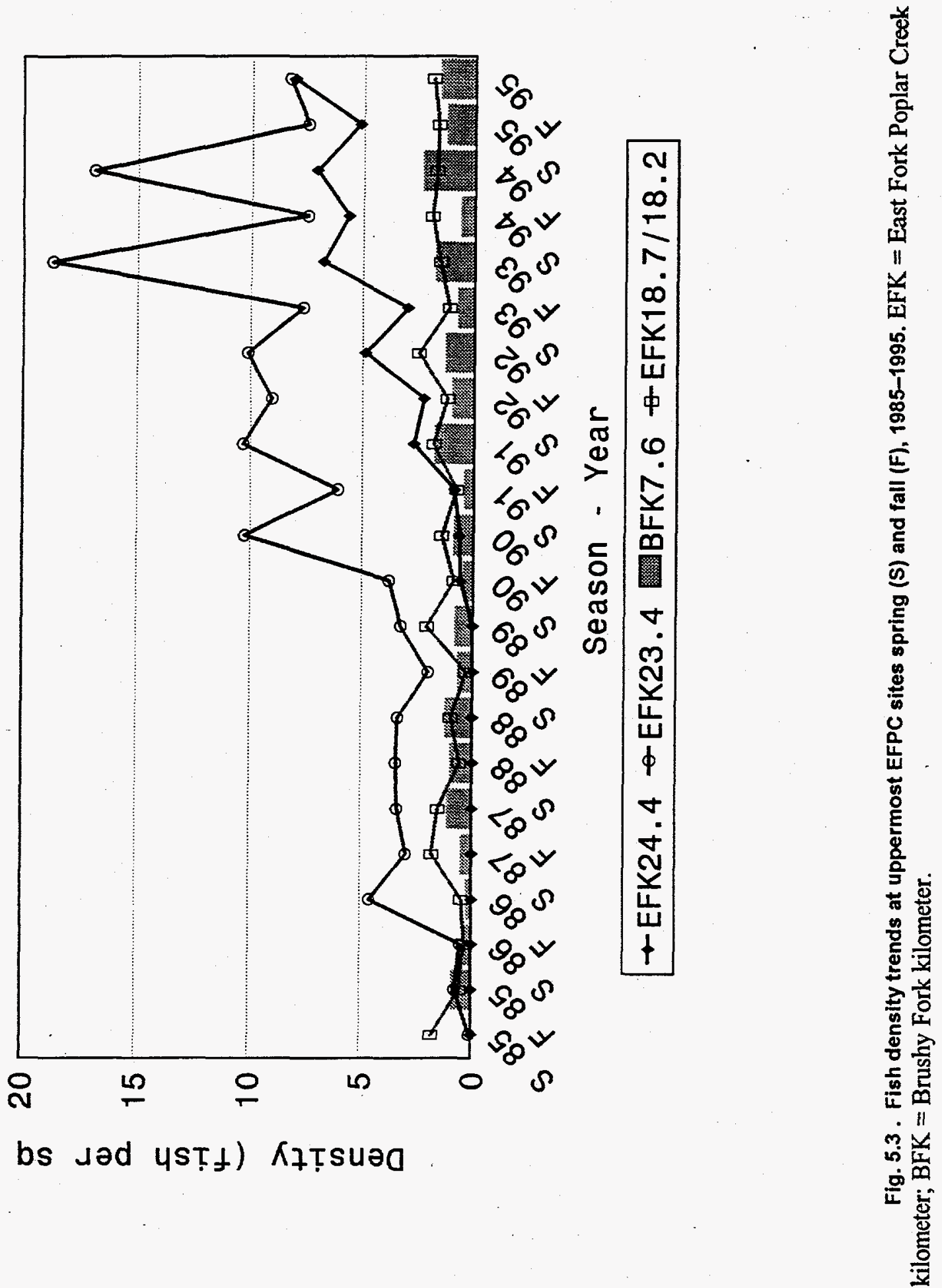

(แ bs Jəd usṬt) КłṬsuəa 
outfalls in late 1992 reduced the mortality from chronic toxicity, and kills from acutely toxic conditions are rarely a factor in upper EFPC.

Table 5.3. Site designations, sample dates, sites for electrofishing sampling of the Fish Community Studies Task

\begin{tabular}{|c|c|c|}
\hline Site & Sample dates & Comments \\
\hline EFK $^{a} 25.1$ & $\begin{array}{l}\text { Oct. } 1989 \text { to } \\
\text { present }\end{array}$ & $\begin{array}{l}\text { Site added to monitor fish community at the most } \\
\text { upstream location }\end{array}$ \\
\hline EFK 24.4 & $\begin{array}{l}\text { Jun. } 1985 \\
\text { to } \\
\text { present }\end{array}$ & $\begin{array}{l}\text { Site shifted upstream and shortened from } 234 \text { to } \\
109 \mathrm{~m} \text { in fall } 1989 \text { in response to presence of } \\
\text { fish; site may be shifted for safety concerns as } \\
\text { flow is increased in upper EFPC }\end{array}$ \\
\hline EFK 23.4 & $\begin{array}{l}\text { May } 1985 \\
\text { to } \\
\text { present }\end{array}$ & $\begin{array}{l}\text { Site shortened from } 116 \text { to } 90 \mathrm{~m} \text { in October } 1987 \\
\text { following increase in fish abundance }\end{array}$ \\
\hline EFK 18.7 & $\begin{array}{l}\text { Mar. } 1990 \\
\text { to } \\
\text { present }\end{array}$ & Site added as replacement for EFK 18.2 \\
\hline EFK 13.8 & $\begin{array}{l}\text { May } 1985 \text { to } \\
\text { present }\end{array}$ & $\begin{array}{l}\text { Site shifted upstream in September } 1992 \text { and } \\
\text { March } 1993 \text { when raw sewage flowed into } \\
\text { sampling reach }\end{array}$ \\
\hline EFK 6.3 & $\begin{array}{l}\text { Jun. } 1985 \\
\text { to } \\
\text { present }\end{array}$ & \\
\hline $\mathrm{BFK}^{b} 7.6$ & $\begin{array}{l}\text { Nov. } 1985 \\
\text { to } \\
\text { present }\end{array}$ & Reference site \\
\hline $\mathrm{HCK}^{c} 12.9$ & $\begin{array}{l}\text { Mar. } 1991 \\
\text { to } \\
\text { present }\end{array}$ & Reference site \\
\hline
\end{tabular}

${ }^{a}$ East Fork Poplar Creek kilometer.

${ }^{b}$ Brushy Fork kilometer.

'Hinds Creek kilometer. 


\subsubsection{Sampling Procedures}

Quantitative sampling of the fish populations will be conducted at six sites in EFPC and at a site in each of two reference streams, BF and Hinds Creek (Table 5.3), by electrofishing in March-April and September-October. The resulting data will be used to estimate population size (numbers and biomass per unit area), determine community structure, estimate production, and calculate Index of Biotic Integrity (IBI) values.

The current sampling plan for EFPC recognizes the improvement in fish communities that occurred in reaches downstream from the ORR from 1988 to 1993 . Data from sampling in fall 1993 indicate that populations are established at sites upstream and downstream of EFK 24.7 and knowledge gained by further sampling is negligible.

In general, sampling reaches at most sites are about $100 \mathrm{~m}$ in length. Although a longer sample reach (e.g., $200 \mathrm{~m}$ ) would be preferable for determination of species richness, $100 \mathrm{~m}$ is about the maximum length that can be reasonably sampled for density and biomass parameters.

All stream sampling will be conducted with pulsed, direct current electrofishers. At shallow sites, two or three backpack models will be used; in deeper areas, a barge-based electrofisher with a stronger generator may be used. Seines (0.64-cm mesh) are stretched across the upper and lower boundaries of the reach to restrict fish movement and a 5- to 10-person sampling team makes three consecutive passes through the study reach in an upstream direction. Stunned fish are collected and stored by pass during further sampling. Fish are anesthetized with MS-222 (tricaine methanesulfonate), identified, measured, and weighed. After processing fish by pass, the fish are allowed to recover fully from the anesthetic and are returned to the stream. Any additional mortality occurring as a result of processing is noted at that time. All field sampling is conducted according to specific quality control and standard operating procedures (Ryon 1992b).

Species population estimates are calculated using the method of Carle and Strub (1978). Biomass is estimated by multiplying the population estimate by the mean weight per individual. To calculate density and biomass per unit area, total numbers and biomass are divided by the surface area (in square meters) of the study reach. For each sampling date, surface area is estimated by multiplying the length of the reach by the mean width based on measurements taken at $5-\mathrm{m}$ intervals. The population structure of the most abundant species will be examined by length frequencies. The lengths of the selected fish population are separated into 1- to 5-cm size classes, depending on the maximum size of the species. These frequencies 
indicate whether the population includes young and adult individuals and if any unusual mortality has affected a size class. Annual production is estimated using a size-frequency method (Garman and Waters 1983). Production is calculated for each site from the spring of year one to the spring of year two. These data are compiled and analyzed by a comprehensive Fortran 77 program developed by Railsback et al. (1989) according to standard operating procedures (Ryon 1992b).

The fish population data at each site will also be analyzed using the IBI, a fish community assessment that includes measures of species richness and composition, trophic composition, and fish abundance and condition (Karr 1981; Karr et al. 1986). As suggested by Karr and others (Karr et al. 1986, Ohio EPA 1988), modifications were made to the basic IBI metrics to reflect differences in the Clinch River System in the Oak Ridge area, which includes EFPC (Ryon 1993b).

In the previous plan, additional community analyses included species condition factors, and age and growth of target sunfish (Loar et al. 1989). These analyses are no longer conducted by the Fish Community Studies task because they failed to differentiate between sites in a consistent pattern (Ryon and Schilling 1995). The limited set of water quality parameters that were measured prior to sampling in conjunction with the fish community task at all sites will be discontinued, because they provided no indication of stressful conditions. However, turbidity measurements will continue being collected by the fish community task to document sampling conditions for electrofishing.

\subsubsection{Special Studies}

In addition to the routine fish community monitoring, limited habitat studies will be conducted to determine specific factors that may be affecting fish community structure. Because monitoring at a community level reflects the integrative impacts of pollutants, habitat differences, and natural ecological interactions (e.g., competition, predation), it could be helpful to assess how some of these variables shape the existing communities in upper EFPC. Limitations imposed by the existing habitat in upper EFPC could be a principal determinant of the fish community structure. Habitat has been shown to be a critical factor in fish community composition (Gorman and Karr 1978, McClendon and Rabeni 1987, Wesche et al. 1987), and there is reason to suspect it limits the communities in EFPC. Any special studies would focus on specific aspects of habitat and perhaps modifications to increase critical habitat parameters such as riparian cover or instream cover. These investigations could involve manipulative field studies or limited laboratory evaluations.

\section{5-12 Instream Ecological Monitoring}




\section{Data Integration and Interpretation (Task 5)}

\section{S. W. Christensen}

The BMAP has measured various parameters in assessing the ecological health of EFPC over the past decade. This extensive set of data is a resource designed to meet several major objectives (as outlined in Sect. 1). Meeting these objectives is a substantial challenge with respect to data analysis and interpretation. Even the most fundamental objective-i.e., determining whether growth and propagation of fish and aquatic life are protected-inherently involves analysis and interpretation. Unlike comparing the concentration of a chemical in water with a specified standard that is not to be exceeded, "protection of growth and propagation" requires evaluation and judgment about what would be expected in a nonimpacted setting and comparison and interpretation of the site-specific results. The other objectives are even more demanding of analysis and interpretation. In particular, evaluating trends and changes in response to remediation, the current focus, is more difficult than evaluating the ecological status and condition of EFPC, which was the initial focus.

One approach to meeting the increasing demand for data analysis and interpretation is to perform integrative analyses that jointly consider multiple responses, especially responses measured by more than one BMAP task. Such analyses, however, require an integrated database if they are to be carried out effectively and efficiently. The need for an integrated database is also driven by many other factors. The continuing collection of large amounts of data make some centralization of data management an efficient approach, as well as one supporting the needs of the principal investigators. Regardless of these benefits, the Federal Facilities Agreement (FFA) and the Tennessee Oversight Agreement (TOA) (OREIS 1993) both require data integration. Analyses that integrate across the BMAP tasks, which is made possible by use of integrated databases, are also needed for ecological risk assessment activities under the Comprehensive Environmental Response, Compensation and Liability Act.

To meet these needs, an integrated BMAP database has been established and populated with historical and ongoing BMAP data. The primary purpose of this database is to facilitate sending the complex biological BMAP data to the Oak Ridge Environmental Information System (OREIS). Secondary benefits include support of Principal Investigators' (PIs') needs and providing the capability to perform integrative analyses of BMAP data. 


\subsection{DATA INTEGRATION (SUBTASK 5a) (S. W. Christensen and C. C. Brandt)}

\subsubsection{Introduction}

The requirements and needs for an integrated BMAP database originate from a number of sources. The FFA and the TOA (OREIS 1993) specifically require development of centralized data facilities that can make data available to regulators and the public. Because of the increasing extent and complexity of the data and the shift from evaluating status (ecological health) to evaluating changes (ecological recovery), there is also a greater need to share data more effectively among BMAP tasks.

Concurrent with these needs, the capability for meaningful and practical data integration has increased markedly in recent years. Computer workstation technology and the expanding and maturing of electronic networks provide environments conducive to the development of large-scale databases and to the effective use of such databases. The expansion of data modeling as a critical adjunct of database development,.: together with advances in software, made possible development of a unified BMAP database. This database can easily be maintained, can support data integration across BMAP, and greatly facilitates providing BMAP data to the Oak Ridge Environmental Information System (OREIS 1992, 1993) as required under the FFA and the TOA.

\subsubsection{Review of Previous Work}

Historically, data management within BMAP was handled at the task level or the subtask level. This strategy was appropriate for an evolving program, in which sampling design, location, and intensity needed to be flexible as more was learned about the aquatic system. It was also consistent with common practice, where large-scale data integration was seldom attempted. Although valuable if done carefully, data integration efforts can be expensive, and have often proved to be of limited value outside the individual programs collecting the data (e.g., Rosen et al. 1988). The BMAP PIs carried out data management activities on four computer operating systems (mainframe MVS, mainframe VMS, PC/DOS/Windows, and MacIntosh). Statistical analyses were conducted within each task or subtask, using data from that subtask, and summary results are presented. It was not practical to attempt broad-based analyses, either statistical or quantitative, that cut across these disparate systems. Rather, interpretation of the results was based on joint consideration of the summary information from each task or subtask. Although this procedure was adequate for meeting the BMAP objectives at that time, it did not meet regulatory requirements for data

\section{6-2 Data Integration and Interpretation}


integration, did not efficiently support the data needs of risk assessment activities, and did not allow for the broadest interpretive analysis of the BMAP data.

A UNLX workstation was acquired for BMAP in 1993 under other funding. This workstation was shared for several years with the ORNL Waste Area Grouping (WAG) 2 program. Its primary purpose was to facilitate development and use of an integrated BMAP database, based on the use of computer-aided systems engineering (CASE) methods. These methods were used in fiscal years (FY) 1994-1995 to develop a data model for BMAP. In essence, the data model is a common language for transmitting information from the PI to the user. The model development process involved extensive discussions with the PIs, and it was done in cooperation with the WAG 6 and the Clinch River Environmental Restoration Program (CRERP). As a result of this process, a biota data model was developed, and the relational database structure was produced. This model relates the various elements of the BMAP data to each other, ensuring consistent data structures through time and across data types. This biota data model was also used in the WAG 6/CRERP data model. This resulted in cost savings to each program, in model development and in common use of associated procedures and computer codes.

During FY 1996-1997, historical BMAP data were converted into the integrated database structure. Priorities for this work were established in large part by needs of ecological risk assessors, and infrastructure development was funded in part by funding through central Compliance and Environmental Restoration organizations. Reference tables in the WAG 6/CRERP database (e.g., data tables with detailed information about sampling station locations and characteristics or with taxonomic identification information) were expanded to incorporate information and values needed to support the BMAP database; and additional methods documentation, business rules, and work aids were developed. Data on bioindicators, contaminant bioaccumulation, ambient toxicity tests, fish communities, and benthic macroinvertebrate communities were processed and loaded. In addition, an effort undertaken cooperatively with OREIS and CRERP to develop the biota data model for the OREIS database was completed. This model was used to develop the Ready-to-Load (RTL) format specifications. These are being used to move the BMAP biota data, as well as other compliance biota data, into OREIS.

\subsubsection{Description of approach / methodology}

During FY 1998, data integration activities will continue to apply, and modestly expand, these technologies within BMAP. In the approach to data management chosen for BMAP, the PIs will continue to acquire the 
data, assemble basic two-dimensional databases (e.g., ASCII files, spreadsheets, SAS data sets), and :: perform QA/QC reviews before providing them to the central BMAP database. These activities are carried out in accordance with Standard Operating Procedures (SOPs) for each task under the overall BMAP QA/QC plan (Phipps 1995). SAS software is provided on the workstation as a pathway for integration. This workstation-based version of SAS, accessed through X terminal emulation, now provides the PIs with extended and more effective analysis capability than was available on the mainframes. ORACLE software contains the integrated database. ARC/NNFO (including ARC/VIEW) software provides geographic information system (GIS) capability. SAS, ORACLE, and ARC/MNFO were chosen, in part, because of their effectiveness and broad acceptance, but also because these are the software packages used for these purposes by OREIS. We will continue to use these tools.

Data integration activities associated with loading data to the BMAP database, and then to OREIS, are as follows:

- Receive data from PIs

- Register data in the Electronic Data Registration System and check into the Revision Control System.

- Prepare file for processing (when needed).

- Read data into SAS.

- Edit data, including adding unique sample identifiers and observation identifiers.

- Standardize data, including adding additional variables, translating site identifiers into BMAP standard nomenclature, and transposing data to put it in the form required by the BMAP and OREIS relational databases.

- Normalize the data, creating one data set for each table that will receive data.

- Check constraints, and resolve any that may be violated. When this occurs, processing usually resumes from a prior step after problems are corrected.

- Load data to the BMAP database.

- Reprocess data, incorporating corrections to or adjustments of the data if needed. This includes occasional incorporation of changes in taxonomic nomenclature.

- Generate OREIS deliverables from the BMAP database in OREIS RTL format.

- Check the RTL data sets.

- Transmit data to OREIS with required paperwork.

\section{6-4 Data Integration and Interpretation}


- Interact with OREIS to resolve issues that may arise as OREIS processes the deliverables.

- Review OREIS data release packages and, after resolving necessary issues, approve release of the data to the OREIS community.

- Submit OREIS change requests as needed, primarily to handle PI-requested corrections to or updates of their data or updates of reference tables.

- Perform workstation system administration (including backups), software renewals, and hardware maintenance and replacement are necessary activities that make these activities possible.

A number of additional activities related to data integration are either necessary or highly desirable, and these will be carried out as resources permit. To minimize disturbance to the data processing infrastructure used to provide data to OREIS, assistance is provided to OREIS from time to time in areas in which BMAP has expertise (such as taxonomic nomenclature and key attributes) and in areas in which BMAP has an active interest (such as agreement on a structure for and list of results qualifier codes, which could require more extensive changes in our processing infrastructure if not handled properly). Requests for data or information from BMAP PIs are met when possible, particularly in making available to them their data from the BMAP database. Metadata, in the form of explanatory information about the data, will continue to be developed as resources permit by data management staff or by PIs as resources permit. Support, primarily training, will continue to be provided to the BMAP PIs and other staff in such areas as using computer network technology to access the workstation and on the UNLX operating system. Assistance will be provided to PIs for some specific uses of the BMAP workstation. For example, a Fortran program, formerly used on the STC10 mainframe system, is being adapted to the workstation environment, where it will continue to support some analyses of the fish community studies data. Views to the data will continue to be developed to enable data from the database to be provided to the PIs in a familiar format.

Other BMAPs, as well as central funding sources, have contributed to the development of a centralized database for the BMAP data and to the development of OREIS' capability to accept biological data. The other BMAPs also contribute to ongoing activities with OREIS to maintain the necessary structures for dealing with biological data.

Regulators currently have access to data in OREIS through the Internet using X-Window terminals, and to summary data using a Web browser. 


\subsection{INTERPRETATION OF BIOTIC CHANGES (SUBTASK 5B) ( $S . W$. Christensen, C. C. Brandt, and M. A. Huston)}

\subsubsection{Introduction}

Interpreting biotic changes is required to meet BMAP objectives: identifying causes/sources of impact and determining whether recovery has followed remediation (including the integration of responses at different levels of biological organization). These objectives are currently addressed by the existing analyses conducted by the PIs on their individual data. This Interpretation of Biotic Changes Subtask under current funding cannot actively support such interpretations. We can provide only for limited support of the BMAP PIs, as already indicated in Sect. 6.1. However, this task could more fully meet these objectives by (1) coordinating and assisting in the analysis of the integrated data from multiple tasks described in Sect. 6.1; and (2) obtaining and using information from outside BMAP that supports interpretation, such as information from other programs and organizations (Environmental Management and Enrichment Facilities, compliance, and research) and organizations (e.g., TVA).

\subsubsection{Review of Previous Work}

During previous years, a number of approaches have been taken within BMAP to investigate the status of biological communities and the factors affecting them. As a component of the ORNL BMAP, a regional Tennessee Valley database was developed, including fish, benthic invertebrate, and physicochemical data from 107 sites in 7 river systems. The theoretical framework chosen for analysis of the regional database is the dynamic equilibrium theory of community structure (Huston 1979). This theory is based on the balance between the effects of competition, which tend to cause local extinction and reduce species diversity, and the effects of mortality-causing disturbance, which can either increase diversity (by preventing extinction caused by competition) or reduce diversity (by killing most species).

To show how the regional context of EFPC sampling stations can be evaluated, BMAP data for fish and benthic invertebrates could, in future years, be compared with data from these regional sites, in relation to indices of stream flow and velocity. In general, streams with higher discharge volume and lower gradients would be expected to have greater temporal and spatial stability of environmental conditions, and streams of intermediate size would be expected to have the highest productivity because of the interaction between light availability and nutrient concentrations. Smaller streams tend to have lower stability of environmental conditions, both temporally and spatially. These physical and environmental conditions influence population dynamics, competition, and predator/prey interactions; and they are important to 
consider when relating patterns in the biological data to anthropogenic effects. When this approach was used with BMAP data from streams in the White Oak Creek watershed, interpretable differences were found in patterns of fish species richness, biomass, and guild structure, and of invertebrate density and taxonomic richness, indicating clear effects of ORNL operations (Huston 1990, 1994).

\subsubsection{Description of Planned Approach}

Within the Data Integration and Interpretation Task, all effort in FY 1998 will continue to be devoted to the data integration component, as described in Sect. 6.1, and particularly to transmitting data to OREIS. Efforts will be focused there because of the external requirements for data integration; the activities described in Sect. 6.1 require all available funding. However, the integrated BMAP database would enable future activities in the Interpretation of Biotic Changes Subtask, as described below, if funds were available.

While some analyses could continue to use the regional Tennessee Valley database, most of the effort in this Interpretation of Biotic Changes Subtask would shift toward using the very extensive BMAP data collected for more than a decade and the increasingly high-quality physical data available for the ORR.

Discussions among the PIs will continue to identify types of integrative analysis of the BMAP data, which would lead to better identification of impacts or a better understanding of spatial/temporal patterns in the data. Analysis methods could be sought that would address those opportunities. In future years, GIS approaches could be used to assist with the interpretation of the BMAP data in the integrated BMAP database. For example, an interpretive GIS could be developed to integrate the results of hydrologic flow data, hydrologic models, and vegetation and land use information from satellite imagery to characterize spatial and temporal variation that are likely to impact streams on the ORR.

The extent and quality of the BMAP long-term data make possible numerous internal comparisons and analyses. The data are multidimensional, with dimensions of space, time (seasonal and annual), status (impacted or reference), and type of biotic measure (e.g., benthic invertebrate total density and taxonomic richness, fish population size and biomass, and many other indices). Comparisons can, therefore, be made between seasons, among sites along a stream, between reference and impacted sites, between years, before and after impacts, and among different types of biota. Use of ORR data and satellite imagery provide additional information to help interpret the BMAP data. 
The most fundamental need for analysis of BMAP data is to be able to draw strong inferences about causes of impact and responses to remediation. Ecological risk assessment (Suter 1993) recognizes the existence and implications of multiple causes of change. It is important to identify both positive and negative causes of change and to separate change driven by natural causes from change resulting from anthropogenic causes. Multiple lines of evidence, including laboratory toxicity tests and studies as well as field observations, are used to reach strongly supported conclusions (Suter and Loar 1992a).

A primary goal of the Data Integration and Interpretation Task could be to assist BMAP PIs in the interpretation of their own data by providing additional data that are not currently available in a form that is readily interpretable. A vital aspect both of integrative and interpretive analyses is that of communicating the data clearly, both internally for integration and synthesis, and externally to sponsors and the public. Such augmentation and the use of integrated data would enable clear data communication by providing documentation, developing consistent terminology and units, ensuring that appropriate and complete data are included, and enabling linkage of data from different BMAP tasks. 


\section{References}

Adams, S. M., and McLean, R. B. 1985. Estimation of largemouth bass, Micropterus salmoides Lacepede, growth using the liver somatic index and physiological variables. J. Fish. Biol. 26:111-126.

Adams, S. M. 1990a. Status and use of biological indicators for evaluating the effects of stress on fish. IN: S. M. Adams (ed.), Biological Indicators of Stress in Fish. Amer. Fish. Soc. 8:1-8.

Adams, S. M. 1990b. Biological Indicators of Stress in Fish. Amer. Fish. Soc. Sym. No. 8. Amer. Fish. Soc., Bethesda, Maryland.

Adams, S. M., and M. S. Greeley, Jr. 1991. Assessment and evaluation of the ecological health of fish populations exposed to PCBs in Hartwell Reservoir. Tennessee Valley Authority Publ. TVA/WR/AB-91/14, Chattanooga, Tennessee.

Adams, S. M., and M. S. Greeley, Jr. 1993. Biological indicators of contaminant-related stress, Sec. 5, pp. 1-60. IN: R. L. Hinzman (ed.), Second Report on the Oak Ridge Y-12 Plant Biological Monitoring and Abatement Program for East Fork Poplar Creek. Y/TS-888. Oak Ridge National Laboratory, Oak Ridge, Tennessee.

Adams, S. M., W. D. Crumby, M. S. Greeley, Jr., M. G. Ryon, and E. M. Schilling. 1992a. Relationships between physiological and fish population responses in a contaminated stream. Environ. Toxicol. Chem. 11:1549-1557.

Adams, S. M., W. D. Crumby, M. S. Greeley, Jr., and L. R. Shugart. 1992b. Responses of fish populations and communities to pulp mill effluents: a holistic assessment. Ecotoxicol and Environ. Safety $24: 347-360$.

Adams, S. M., K. L. Shepard, M. S. Greeley, Jr., B. D. Jimenez, M. G. Ryon, L. R. Shugart, J. F. McCarthy, and D. E. Hinton. 1989. The use of bioindicators for assessing the effects of pollutant stress on fish. Mar. Environ. Res. 28:459-464. 
Ankley, G. T., D. E. Tillit, J. P. Giesy, P. D. Jones, and D. A. Verbrugge. 1991. Bioassay-derived 2,3,7,8-tetrachlorodibenzo- $p$-dioxin equivalents in PCB-containing extracts from the flesh and eggs of Lake Michigan chinook salmon (Oncorhyncus tshawytscha) and possible implications for reproduction. Can. J. Fish. Aquat. Sci. 48: 1685-1690.

Ashwood, T. L., et al. 1994. Eighth Annual Report on the ORNL Biological Monitoring and Abatement Program. Draft ORNL/TM-12767. Oak Ridge National Laboratory, Oak Ridge, Tennessee.

Birge, W. J., J. A. Black, and A. G. Westerman. 1985. Short-term fish and amphibian embryo-larval tests for determining the effects of toxicant stress on early life stages and estimating chronic values for single compounds and complex effluents. Environ. Toxicol. Chem. 4: 807-821

Boston, H. L., W. R. Hill, and A. J. Stewart. 1991. Evaluating direct toxicity and food chain effects in aquatic systems using natural periphyton communities, pp. 126-145. IN: J. W. Gorsuch, W. R. Lower, and K. R. St. John (eds.), Plants for Toxicity Assessment: Second Volume. ASTM STP 1115.

Boston, H. L., W. R. Hill, and A. J. Stewart. 1993. Toxicity Monitoring. IN: R. L. Hinzman (ed.), Second Report on the Oak Ridge Y-12 Plant Biological Monitoring and Abatement Program for East Fork Poplar Creek. Y/TS-888. Oak Ridge National Laboratory, Oak Ridge, Tennessee.

Cairns, J. and W. H. van der Schalie. 1980. Biological monitoring: Part I-early warning systems. Water Research 14:1179-1196.

Capuzzo, J. M. 1985. Biological effects of petroleum hydrocarbons on marine organisms: integration of experimental results and predictions of impacts. Mar. Environ. Res. 17:272-276.

Carle, F. L., and M. R. Strub. 1978. A new method for estimating population size from removal data. Biometrics 34:621-630.

CDM Federal Programs Corporation. 1994. Water Balance Report. Oak Ridge, Tennessee.

\section{R-2 References}


Chagnon, N. L. and S. I. Guttman. 1989. Differential survivorship of allozyme genotpes in mosquitofish populations exposed to copper or cadium. Environ. Toxicol. Chem. 8:319-326.

Chambers, J. E. and J. D. Yarbrough. 1976. Xenobiotic biotransformation systems in fishes. Comparative Biochem. Physiol. 55C:77-84.

Constable, M., and P. Orr. 1994. Lethal and sub-lethal toxicity of lindane to Pimephales promelas and Ceriodaphnia dubia. Bull. Environ. Toxicol. Chem. 52:298-304.

Cook, R. B. et al. 1993. Phase 2 sampling and analysis plan, quality assurance project plan, and health and safety plan for the Clinch River remedial investigation. Dept. of Energy, Oak Ridge National Laboratory, DOE/OR/01-1111\&D3.

Diamond, J. M., M. J. Parson, and D. Gruber. 1990. Rapid detection of sublethal toxicity using fish ventilatory behavior. Environ. Toxicol. Chem. 9:3-11.

DOE (U.S. Department of Energy). 1994a. East Fork Poplar Creek-Sewer Line Beltway Remedial Investigation Report. DOE/OR/02-1119\&D2. Prepared by Science Applications International Corporation, Oak Ridge, Tennessee; Submitted to U.S. Department of Energy under Contract No. DE-AC05-910R21950.

DOE (U.S. Department of Energy). 1994b. Feasibility Study for the Lower East Fork Poplar Creek-Sewer Line Beltway. DOE/OR/02-1185\&D2, Volumes 1 and 2. Prepared by Science Applications International Corporation, Oak Ridge, Tennessee; Submitted to U.S. Department of Energy under Contract No. DE-AC05-910R21950.

DOE (U.S. Department of Energy). 1994c. Addendum to the East Fork Poplar Creek-Sewer Line Beltway Remedial Investigation Report. DOE/OR/02-119\&D2/A1/R1. Prepared for U.S. DOE by Science Applications International Corporation (SAIC), Oak Ridge, Tennessee. 
DOE (U.S. Department of Energy). 1995a. Remedial Goal Options for Mercury in Sediment of East Fork Poplar Creek, Oak Ridge, Tennessee. DOE/OR/01-1342\&D2. Prepared for U.S. DOE by Science Applications International Corporation (SAIC), Oak Ridge, Tennessee.

DOE (U.S. Department of Energy). 1995b. Proposed Plan, East Fork Poplar Creek-Sewer Line Beltway, Oak Ridge, Tennessee. DOE/OR/02-1209\&D3.

DOE (U.S. Department of Energy). 1995c. Record of Decision for Lower East Fork Poplar Creek, DOE/OR/02-1370\&D1.

DOE (U.S. Department of Energy). 1995. Mercury abatement report on the U. S. Department of Energy Oak Ridge Y-12 Plant for fiscal year 1995. Y/ER-251, Oak Ridge Y-12 Plant, Oak Ridge, Tennessee.

Elliot, J. M. 1977. Some methods for the statistical analysis of samples of benthic invertebrates. Sci. Pub. No. 25. Freshwater Biological Association, Ambleside, England.

EPA (U.S. Environmental Protection Agency). 1986. Quality Criteria for Water. Office of Water Regulations and Standards, Washington, D.C.

ERDA (Energy Research and Development Administration). 1995. Preliminary Draft Environmental Analysis. Oak Ridge Operations, Vol. VI. Section. 2.5.5. Mimeo.

Etnier, E. L., D. M. Opresko, and S. A. Talmage (eds). 1995. Evaluation of Fish Kills during July 1990 to March 1993 in upper East Fork Poplar Creek near the Y-12 Plant. Draft ORNL/TM-12636. Oak Ridge National Laboratory, Oak Ridge Tennessee.

Fletcher, G. L, M. J. King, J. W. Kiceniuk, and R. F. Addison. 1982. Liver hypertrophy in winter flounder following exposure to experimentally oiled sediments. Comp. Biochem. Physiol. 73C:457-462. 
Freeman, H. C., and D. R. Idler. 1975. The effect of polychlorinated biphenyl on steroidogenesis and reproduction in the brook trout (Salvelinus fontinalis). Can. J. Biochem. 53: 666-670.

Garman, G. C., and T. F. Waters. 1983. Use of the size-frequency (Hynes) method to estimate annual production of a stream fish population. Can. J. Fish. Manag. 6:176-182.

Geraghty and Miller, Inc. 1985. Remedial Alternatives for the Bear Creek Valley Waste Disposal Area. Final Report No. Y/SUB/85-00206C/3. Geraghty and Miller, Inc. Tampa, Florida.

Gillespie, R. B., and S. I. Guttman. 1989. Effects of contaminants on the frequencies of allozyme in populations of the central stoneroller. Environ. Toxicol. Chem. 8:309-317.

Goede, R. W., and Barton, B. A. 1990. Organismic indices and an autopsy-based assessment as indicators of health and condition of fish. Amer. Fish. Soc. Sym. 8:93-108.

Gorman, O. T., and J. R. Karr. 1978. Habitat structure and stream fish communities. Ecology 59:507-515.

Haake-McMillan, J. M., and S. H. Safe. 1991. Neonatal exposure to Arochlor 1254: effects on adult hepatic testosterone hydroxylase activities. Xenobiotica 21: 481-489.

Halter, M. K., and H. E. Johnson. 1974. Acute toxicities of a polychlorinated biphenyl (PCB) and DDT alone and in combination to early life stages of coho salmon (Oncorhyncus kisutch). J. Fish Res. Board Can. 31: 1543-1547.

Ham, K. D., and M. J. Peterson. 1994. Effect of fluctuating low-level chlorine concentrations on valvemovement behavior of the Asiatic clam (Corbicula fluminea). Environ. Toxicol. Chem. 13:493-498.

Hazel, J. R., and C. L. Prosser. 1974. Molecular mechanisms of temperature compensation in poikilotherms. Physiological Reviews 54:620-677. 
Heath, A. G. 1987. Use of physiological and biochemical measures in pollution biology. pp. 221-234; IN: A. G. Heath (ed.), Water pollution and fish physiology. CRC Press, Boca Raton, Florida.

Heath, A. G. 1990. Summary and Perspectives. IN: S. M. Adams (ed.), Biological indicators of stress in fish. Amer. Fish. Soc. Sym No. 8. Bethesda, MD.

Heidinger, R. C., and S. D. Crawford. 1977. Effect of temperature and feeding rate on the liver-somatic index of the largemouth bass, Micropterus salmoides. J. Fish. Res. Bd. Can. 34: 633-638.

Heisinger, J. F., and W. Green. 1975. Mercuric chloride uptake by eggs of the ricefish and resulting teratogenic effects. Bull. Environ. Contam. Toxicol. 14: 655-673.

Hill, W. R. 1992. Food limitation and interspecific competition in snail-dominated streams. Can. J. Fish. Aquat. Sci. 49:1257-1267.

Hill, W. R., H. L. Boston, and A. D. Steinman. 1992a. Grazers and nutrients simultaneously limit lotic primary productivity. Can. J. Fish. Aquat. Sci. 49:504-512.

Hill, W. R., S. C. Weber, and A. J. Stewart. 1992b. Food limitation of two lotic grazers: quantity, quality, and size specificity. J. N. Amer. Benth. Soc. 11:420-432.

Hill, W. R., A. J. Stewart, and G. E. Napolitano. In Press. Mercury speciation and bioaccumulation in lotic primary producers and primary consumers. Can. J. Fish. Aquat. Sci. 53:000-000.

Hinton, D. E., and D. J. Lauren. 1990. Integrative histopathological approaches to detecting effects of environmental stressors on fishes. Amer. Fish. Soc. Sym. 8:51-66.

Hinton, D. E. 1992. Histopathologic biomarkers. pp. 155-209. IN: R. J. Huggett (ed.), Biomarkers. Lewis Pubs., Boca Raton, Florida. 
Hinzman, R. L., et al. 1993. Second Report on the Oak Ridge Y-12 Plant Biological Monitoring and Abatement Program for East Fork Poplar Creek. Y/TS-888. Oak Ridge Y-12 Plant. Oak Ridge, Tennessee.

Hinzman, R. L., et al. 1995. Third Report on the Oak Ridge Y-12 Plant Biological Monitoring and Abatement Program for East Fork Poplar Creek. Draft Report Y/TS-889, Oak Ridge Y-12 Plant, Oak Ridge, Tennessee.

Hoffman, F. O., B. G. Blaylock, C. C. Travis, K. L. Daniels, E. L. Etnier, K. E. Cowser, and C. W. Weber. 1984. Preliminary Screening of Contaminants in Sediments. ORNL/TM-9370. Oak Ridge National Laboratory, Oak Ridge, Tennessee.

Huston, M. A. 1979. A general hypothesis of species diversity. Am. Nat. 113:81-101.

Huston, M. A. 1992. Interpretation of Biotic Changes. IN: J. M. Loar (ed.), Second Report on the Oak Ridge National Laboratory Biological Monitoring and Abatement Program for White Oak Creek Watershed and the Clinch River. ORNL/TM-10804. Oak Ridge National Laboratory. Oak Ridge, Tennessee.

Huston, M. A. 1994. Interpretation of Biotic Changes. IN: J. M. Loar (ed.), Fourth Report on the Oak Ridge National Laboratory Biological Monitoring and Abatement Program for White Oak Creek Watershed and the Clinch River. ORNL/TM-1 1544. Oak Ridge National Laboratory. Oak Ridge, Tennessee.

Johnson, L. L., E. Casillas, T. K. Collier, B. B. McCain, and U. Varanasis. 1988. Contaminant effects on ovarian development in English sole (Parophyrys vetulus) from Puget Sound, Washington. Can. J. Fish. Aquat. Sci. 45: 2133-2146.

Karr, J. R. 1981. Assessment of biotic integrity using fish communities. Fisheries 6:21-27. 
Karr, J. R., K. D. Fausch, P. L. Angermeier, P. R. Yant, and I. J. Schlosser. 1986. Assessing biological integrity in running waters a method and its rationale. Illinois Natural History Survey Special Publication 5. $28 \mathrm{pp}$.

Karr, J. R. 1987. Biological monitoring and assessment: A conceptual framework. Environ. Manag. 11:249-256.

Kasten, J. L. 1986. Resource Management Plan for the Oak Ridge Reservation, Vol. 21: Water Conservation Plan for the Oak Ridge Reservation. ORNL/ESH-1/V21. Oak Ridge National Laboratory, Oak Ridge, Tennessee.

Kohring, L. L. 1993. Quantitative multi-species toxicity assessment by analysis of freshwater stream periphyton pigments and lipids. M.S. Thesis. University of Tennessee. Knoxville, Tennessee.

Kornegay, F. C., D. C. West, L. W. McMahon, J. B. Murphy, L. G. Shipe, and W. S. Koncinski. 1993. Oak Ridge Reservation Environmental Report for 1992. ES/ESH-31/V1. Environmental, Safety, and Health Compliance and Environmental Management Staffs of the Oak Ridge Y-12 Plant, Oak Ridge National Laboratory, and Oak Ridge K-25 Site, Martin Marietta Energy Systems, Inc., Oak Ridge, Tennessee.

Kszos, L. A., and A. J. Stewart. 1994. Artifacts in ambient toxicity testing. Environ. Toxicol. Chem.

Knuth, M. L. 1979. The incidence of polychlorinated biphenyls and other cklorinated hydrocarbons in raccoon adipose tissue and selected aquatic organisms in the central Wisconsin River basin. M.S. Thesis. University of Wisconsin, Stevens Point.

Kszos, L. A., A. J. Stewart, and P. A. Taylor. 1992. An evaluation of nickel toxicity to Ceriodaphnia dubia and Daphnia magna in a contaminated stream and in laboratry tests. Environ. Toxicol. Chem. 11:1001-1012.

\section{R-8 References}


Larkin, P. A. 1978..Fisheries management: An essay for ecologists. Ann. Rev. Ecol. System. 9:57-73.

Lavie, B., and E. Nevo. 1982. Heavy metal selection of allozymnes in marine organisms: prediction and verification in nature. Mar. Biol. 71:17-22.

Layher, W. G., L. B. Fox, and R. Broxterman. 1987. Environmental contaminants in raccoons in Kansas. Bull. Environ. Contam. Toxicol. 39:926-32.

LeCren, E. D. 1951. The length-weight relationship and seasonal cycle in gonad weight and condition in the perch (Perca fluviatilis). J. Animal Ecology. 20:201-219.

Loar, J. M., S. M. Adams, L. J. Allison, J. M. Giddings, J. F. McCarthy, G. R. Southworth, J. G. Smith, and A. J. Stewart. 1989. The Oak Ridge Y-12 Plant Biological Monitoring and Abatement Program for East Fork Poplar Creek. ORNL/TM-10265. Oak Ridge National Laboratory, Oak Ridge, Tennessee.

Loar, J. M., et al. 1991. Oak Ridge National Laboratory Biological Monitoring and Abatement Program for White Oak Creek Watershed and the Clinch River. ORNL/TM-10370. Oak Ridge National Laboratory. Oak Ridge, Tennessee.

Loar, J. M., et al. 1992a. First Report on the Oak Ridge Y-12 Plant Biological Monitoring and Abatement Program for East Fork Poplar Creek. Y/TS-886. Oak Ridge Y-12 Plant. Oak Ridge, Tennessee.

Loar, J. M., S. M. Adams, L. A. Kszos, M. G. Ryon, J. G. Smith, G. R. Southworth, and A. J. Stewart. 1992b. Oak Ridge Gaseous Diffusion Plant Biological Monitoring and Abatement Program for Mitchell Branch. ORNL/TM-1 1965. Oak Ridge National Laboratory. Oak Ridge, Tennessee.

Lotts, J. W., Jr. and A. J. Stewart. 1995. Minnows can acclimate to total residual chlorine. Environ. Toxicol. Chem. 14(8):1365-1374. 
Mauck, W. L., P. M. Mehrle, and F. L. Mayer. 1978. Effects of polychlorinated biphenyl Arochlor 1254 on growth, survival, and bone development in brook trout (Salvelinus fontinalis). J. Fish. Res. Board Can. 35: 1084-1088.

McClendon, D. D., and C. F. Rabeni. 1987. Physical and biological variables useful for predicting population characteristics of smallmouth bass and rock bass in an Ozark stream. N. Amer. J. Fish. Manag. 7:46-56.

McMasters, W. M. 1967. Hydrologic data for the Oak Ridge area, Tennessee. U.S. Geological Survey-Water Supply Paper No. 1838-N. U.S. Government Printing Office, Washington, D.C.

Miranda, C. L., J.-L. Wang, H.-S. Chang, and D. R. Butler. 1990. Multiple effects of 3,4,5,3',4',5'hexachlorobiphenyl administration of hepatic cytochrome P450 isozymes and associated mixedfunction oxidase activities in rainbow trout. Biochemical Pharmacol. 40:387-390.

Morgan, E. L., R. C. Young, and J. R. Wright, Jr. 1988. Developing portable computer-automated biomonitoring for a regional water quality surveillance network. pp. 127-141. IN: D. Gruber and J. M. Diamond (eds.), Automated biomonitoring: living sensors as environmental monitors. Ellis Horwood, Ltd. London.

Napolitano, G. E., W. R. Hill, J. B. Guckert, A. J. Stewart, S. C. Nold, and D. C. White. 1994. Changes in periphyton community structure, lipid and fatty acid compositions in chlorine-polluted streams. J. North Amer. Benthol. Soc. 13:237-249.

Nebeker, A. V., F. A. Puglisi, and D. L. DeFoe. 1974. Effect of polychlorinated biphenyl compounds on survival and reproduction of the fathead minnow and flagfish. Trans. Amer. Fish. Soc. 103:562-568.

Niimi, A .J. 1990. Review of biochemical methods and other indicators to assess fish health in aquatic ecosystems containing toxic substances. Journal of Great Lakes Research 16:529-541. 
Ohio EPA. 1988. Biological Criteria for the Protection of Aquatic Life: Volume II. Users Manual for Biological Field Assessment of Ohio Surface Streams. Ohio Environmental Protection Agency, Division of Water Quality Monitoring and Assessment, Columbus Ohio.

OREIS (Oak Ridge Environmental Information System). 1992. Data Management Plan for the Oak Ridge Environmental Information System, Version 1.1. ES/ER/TM-39, Environmental Restoration Division, Oak Ridge, Tennessee 37831.

OREIS (Oak Ridge Environmental Information System). 1993. Draft Data Management Plan for the Oak Ridge Environmental Information System, Version 2.0. ES/ER/TM-39/R1, Environmental Restoration Division, Oak Ridge, Tennessee 37831.

Peterson, M. J., G. R. Southworth, and K. D. Ham. 1994. Effect of sublethal chlorinated discharges on PCB accumulation in transplanted Asiatic clams (Corbicula fluminea). Water, Air, and Soil Pollution 73:169-178.

Phipps, T. L. 1995. Environmental Sciences Division Biological Monitoring and Abatement Program Quality Assurance Program Plan. QAP-X-90-ES-063, Rev. 1. Environmental Sciences Division, Oak Ridge National Laboratory, Oak Ridge, Tennessee.

Pritz, P. M., and M. Sanders. 1982. Spill Prevention Control and Countermeasure (SPCC) Plan for Oil and Hazardous Substances at the Oak Ridge Y-12 Plant. Y/DD-242, R2. Oak Ridge Y-12 Plant, Oak Ridge, Tennessee.

Railsback, S. F., B. D. Holcomb, and M. G. Ryon. 1989. A Computer Program for Estimating Fish Population Sizes and Annual Production Rates. ORNL/TM-11061. Oak Ridge National Laboratory, Oak Ridge, Tennessee. 
Rosen, A. E., et al. 1988. An Adirondack Watershed Data Base: Attribute and Mapping Information for Regional Acidic Deposition Studies. ORNL/TM-10144, Oak Ridge National Laboratory, Oak Ridge, Tennessee.

Runck, C. D. 1996. Influence of total suspended solids on nutritional quality of lotic periphyton and implications for secondary production. Bulletin North American Benthological Society 13:185.

Ryan, D. E., P. E. Thomas, and W. Levin. 1982. Purification and characterization of a minor form of hepatic microsomal cytochrome P-450 from rats treated with polychlorinated biphenyls. Arch. Biochem. Biophy. 216: 272-288.

Ryon, M. G. 1992a. Fishes. IN: M. G. Ryon (ed.), Ecological Effects of Contaminants in McCoy Branch, 1989-1990. ORNL/TM-11926. Oak Ridge National Laboratory. Oak Ridge, Tennessee.

Ryon, M. G. 1992b. Biological Monitoring and Abatement Programs: Fish community studies project, Quality Assurance Plan and Standard Operations Procedures. ORNL/FPO-QAP-X-90-ES-067. Oak Ridge National Laboratory, Oak Ridge, Tennessee.

Ryon, M. G. 1993a. Fishes. IN: L. A. Kszos (ed.). Biological Monitoring and Abatement Program for the Oak Ridge K-25 Site. K/EM-24/R2. Oak Ridge National Laboratory. Oak Ridge, Tennessee.

Ryon, M. G. 1993b. Fishes. IN: R. L. Hinzman (ed.). Second Report on the Oak Ridge Y-12 Plant Biological Monitoring and Abatement Program for East Fork Poplar Creek. Y/TS-888. Oak Ridge Y-12 Plant. Oak Ridge, Tennessee.

Ryon, M. G. 1993c. Fishes. IN: J. G. Smith (ed.), First Report on the Oak Ridge K-25 Site Biological Monitoring and Abatement Program for Mitchell Branch. ORNL/TM-11073. Oak Ridge National Laboratory. Oak Ridge, Tennessee.

R-12 References 
Ryon, M. G. 1994a. Fishes. IN: L. A. Kszos (ed.). Report on the Biological Monitoring Program at Paducah Gaseous Diffusion Plant, December 1990 to November 1992. ORNL/TM-12338. Oak Ridge National Laboratory. Oak Ridge, Tennessee.

Ryon, M. G. 1994b. Appendix C. Technical Memorandum for the Portsmouth Baseline Ecological Risk Assessment: Fall (1993) and Summer (1994) Fish Community Surveys. IN: D. M. Steinhauff (ed.), Baseline Ecological Risk Assessment, Portsmouth Gaseous Diffusion Plant, Piketon, Ohio. Volume 3. DOE/OR/11-1316/V3\&D1/Oak Ridge National Laboratory, Oak Ridge, Tennessee.

Ryon, M. G. 1994c. Fishes. IN: J. M. Loar (ed.), Third Report on the Oak Ridge National Laboratory Biological Monitoring and Abatement Program for White Oak Creek Watershed and the Clinch River. ORNL/TM-11358. Oak Ridge National Laboratory. Oak Ridge, Tennessee.

Ryon, M. G. 1994d. Fishes. IN: J. M. Loar (ed.), Fourth Report on the Oak Ridge National Laboratory Biological Monitoring and Abatement Program for White Oak Creek Watershed and the Clinch River. ORNL/TM-11544. Oak Ridge National Laboratory. Oak Ridge, Tennessee.

Ryon, M. G. and E. M. Schilling. 1995. Fishes. IN: R. L. Hinzman (ed.). Third Report on the Oak Ridge Y-12 Plant Biological Monitoring and Abatement Program for East Fork Poplar Creek. Draft Report Y/TS-889, Oak Ridge Y-12 Plant, Oak Ridge, Tennessee.

Ryon, M. G., J. M. Loar, G. R. Southworth, A. J. Stewart, S. M. Adams, and L. A. Kszos. 1990. Evaluation of Fish Kills Occurring During November 1986 and July 1987 in upper East Fork Poplar Creek Near the Y-12 Plant. ORNL/TM-10265, Oak Ridge National Laboratory, Oak Ridge, Tennessee.

SAIC. 1995. East Fork Poplar Creek Ecological Monitoring Program Plan. Final Draft. Oak Ridge, Tennessee. 
SAS Institute, Inc. 1985a. SAS User's Guide: Statistics, Version 5 Edition. SAS Institute, Inc.; Cary, North Carolina.

SAS Institute, Inc. 1985b. SAS User's Guide: Basics, Version 5 Edition. SAS Institute, Inc., Cary, North Carolina.

Sastry, A. N., and D. C. Miller. 1981. Application of biochemical and physiological responses to water quality monitoring. pp. 265-294 IN: F. J. Vernberg, A. Calabrease, F. Thurberg, and W. Vernberg (eds.), Biological monitoring of marine pollutants. Academic Press, New York.

Schimmel, S. C., D. J. Hansen, and J. Forester. 1974. Effects of Arochlor 1254 on laboratory-reared embryos and fry of sheepshead minnows (Cyprinodon variegatus). Trans. Amer. Fish. Soc. 3: 582586.

Selye, H. 1950. Stress and the general adaptation syndrome. British Medical Journal. 1:1383-1392.

Sivarajah, K., C. S. Franklin, and W. P. Williams. 1978. The effects of polychlorinated biphenyls on plasma steroid levels and hepatic microsomal enzymes in fish. J. Fish Biol. 13: 401-409.

Smith, E. P., D. R. Orvos, and J. Cairns, Jr. 1993. Impact assessment using the Before-After-Control-Impact (BACI) model: Concerns and comments. Can. J. Fish. Aquat. Sci. $50: 627-637$.

Smith, J. G., and V. R. Tolbert. 1993. Benthic macroinvertebrates. IN: R. L. Hinzman, (ed.), Second Report on the Oak Ridge Y-12 Plant Biological Monitoring and Abatement Program for East Fork Poplar Creek. Y/TS-888. Oak Ridge National Laboratory, Oak Ridge, Tennessee.

Smith, J. G., and W. C. Dickinson. 1995. Benthic macroinvertebrates. IN: R. L. Hinzman (ed.), Third Report on the Oak Ridge Y-12 Plant Biological Monitoring Program for East Fork Poplar Creek. Draft Y/TS-889, Oak Ridge National Laboratory, Oak Ridge, Tennessee.

\section{R-14 References}


Smith, M. R., and J. G. Smith. 1995. Biological Monitoring and Abatement Program; Benthic Macroinvertebrate Community Studies Quality Assurance Plan, QAP-X-89-ES-068, Rev. 1, November 1995. Oak Ridge National Laboratory, Oak Ridge, Tennessee.

Southeast Directory Company, Inc. 1995. Anderson, Roane, Morgan Counties Telephone Book. September 1995-1996. Knoxville, Tennessee.

Southworth, G. R., J. A. Burris, J. M. Loar, M. G. Ryon, J. G. Smith, and A. J. Stewart. 1992. Ecological Effects of Contaminants and Remedial Actions in Bear Creek. ORNL/TM-11977. Oak Ridge National Laboratory. Oak Ridge, Tennessee.

Stegeman, J. J., and P. J. Kloepper-Sams. 1987. Cytochrome P-450 and monooxygenase activity in aquatic animals. Environ. Health Perspectives 71:87-95.

Stewart, A. J., L. A. Kszos, B. C. Harvey, L. F. Wicker, G. J. Haynes, and R. D. Bailey. 1990. Ambient toxicity dynamics: assessments using Ceriodaphnia dubia and fathead minnow (Pimephales promelas) larvae in short-term tests. Environ. Toxicol. Chem. 9:367-379.

Stewart, A. J., G. J. Haynes, and M. I. Martinez. 1992. Fate and biological effects of contaminated vegetation in a Tennessee stream. Environ. Toxicol. Chem. 11:653-664.

Stewart, A. J., W. R. Hill, and H. L. Boston. 1993. Grazers, periphyton, and toxicant movement in streams. Environ. Toxic. Chem. 12:955-957.

Stewart, A. J., W. R. Hill, K. D. Ham, and S. W. Christensen. 1996. Chlorine dynamics and ambient toxicity in receiving streams. Ecol. Appl. (in press).

Stewart, A. J., and L. A. Kszos. 1990. Toxicity monitoring. IN: J. M. Loar (ed.), Fourth Report on the Oak Ridge National Laboratory Biological Monitoring and Abatement Program. ORNL/TM Report. Oak Ridge National Laboratory, Oak Ridge, Tennessee. 
Stripp, R. A., S. M. Adams, L. Kromidas, and I. D. Trombetta. In Press. Ultrastructural analysis of redbreast sunfish (Lepomis auritus) gill exposed to mixed contaminants:The role of oxidative stress. J. Toxicol. Environ. Health.

Suter, G. W. II, A. E. Rosen, E. Linder, and D. F. Parkhurst. 1987. Hazard assessment. Endpoints for responses of fish to chronic toxic exposures. Environ. Toxicol. Chem. 6:793-809.

Suter, G. W. II, and J. M. Loar. 1992. Weighing the ecological risk of hazardous waste sites: The Oak Ridge case. Environ. Sci. Tech. 26:432-438.

Suter, G. W. II. 1993. Ecological Risk Assessment. Lewis Publishers.

TVA (Tennessee Valley Authority). 1985. Instream Contaminant Study, Task 3: Sediment Tranport Report to U.S. Department of Energy, Oak Ridge Operations Office. Office of Natural Resources and Economic Development, Tennessee Valley Authority, Knoxville, Tennessee.

TVA (Tennessee Valley Authority). 1986. Instream Contaminant Study, Task 5: Summary Report. Report to U.S. Department of Energy, Oak Ridge Operations Office. Office of Natural Resources and Economic Development, Tennessee Valley Authority, Knoxville, Tennessee.

Wallace, J. B., D. S. Vogel, and T. F. Cuffney. 1986. Recovery of a headwater stream from an insecticide-induced community disturbance. J. N. Amer. Benthol. Soc. 5:115-126.

Wesche, T. A., C. M. Goertler, and C. B. Frye. 1987. Contribution of riparian vegetation to trout cover in small streams. N. Amer. J. Fish. Manag. 7:151-153.

Williams, D. D., and H. B. N. Hynes. 1976. The recolonization mechanisms of stream benthos. Oikos 27:265-272.

\section{R-16 References}


Williams, D. D., and H. B. H. Hynes. 1977. Benthic community development in a new stream. "Can. J. of Zool. 55:1071-1076. 


\section{Distribution}

S. M. Adams

C. C. Brandt

L. Bunting, TDEC

D. S. Cicerone

S. W. Christensen

P. E. Davis, TDEC

M. S. Greeley Jr.

C. C. Hill

W. R. Hill

M. A. Huston

L. A. Kszos

E. C. Leming, TDEC/DOE-O

J. M. Loar

J. F. McCarthy

S. D. Morris, DOE

M. J. Peterson

M. G. Ryon

B. E. Skaggs

J. G. Smith

G. R. Southworth

A. J. Stewart

L. O. Vaughan

M. C. Wiest Jr.

EC Document Center-RC

WCD Files

Y-12 Central Files/DOE-OSTI (3) 